\title{
Effect of rumen-protected branched-chain amino acid supplementation on production- and energy-related metabolites during the first 35 days in milk in Holstein dairy cows
}

\author{
F. A. Leal Yepes, ${ }^{1}$ S. Mann, ${ }^{2}$ T. R. Overton, ${ }^{1}$ C. M. Ryan, ${ }^{1}$ L. S. Bristol, ${ }^{2}$ G. E. Granados, ${ }^{1}$ D. V. Nydam, ${ }^{2}$ \\ and J. J. Wakshlag ${ }^{3 *}$ \\ ${ }^{1}$ Department of Animal Science, Cornell University, Ithaca, NY 14853 \\ ${ }^{2}$ Department of Population Medicine and Diagnostic Sciences, College of Veterinary Medicine, Cornell University, Ithaca, NY 14853 \\ ${ }^{3}$ Department of Clinical Sciences, College of Veterinary Medicine, Cornell University, Ithaca, NY 14853
}

\begin{abstract}
Essential AA are critical for multiple physiological processes. Branched-chain AA (BCAA) supplementation has beneficial effects on body weight, lipogenesis, and insulin resistance in several species. The BCAA are used for milk and body protein synthesis as well as being oxidized by the tricarboxylic acid cycle to produce ATP during catabolic states. The objective was to evaluate the effect of rumen-protected BCAA (375 g of $27 \%$ L-Leu, $85 \mathrm{~g}$ of $48 \%$ L-Ile, and $91 \mathrm{~g}$ of $67 \%$ L-Val) with or without propylene glycol (PG) oral administration on milk production, dry matter intake, nonesterified fatty acids, $\beta$-hydroxybutyrate, and plasma urea nitrogen during the first $35 \mathrm{~d}$ in milk (DIM) in dairy cattle. Multiparous Holstein cows were enrolled in blocks of three $28 \mathrm{~d}$ before expected calving and assigned randomly to either the control or 1 of 2 treatments. The control $(\mathrm{n}=26)$ received $200 \mathrm{~g} / \mathrm{d}$ of dry molasses, the BCAA treatment $(\mathrm{n}=23)$ received BCAA mixed with $200 \mathrm{~g} / \mathrm{d}$ of dry molasses from calving until 35 DIM, and the BCAA plus PG (BCAAPG) treatment $(\mathrm{n}=25)$ received BCAA mixed with 200 $\mathrm{g} / \mathrm{d}$ of dry molasses from calving until 35 DIM plus $300 \mathrm{~mL}$ of PG once daily from calving until 7 DIM. Postpartum, dry matter intake least squares means (LSM; 95\% confidence interval) were 20.7 (19.9, 21.7), $21.3(20.4,22.3)$, and $21.9(20.9,22.8) \mathrm{kg}$ for control, BCAA, and BCAAPG, respectively. Milk yield (1-35 DIM) LSM were $41.7(39.4,44.0), 42.7(40.3,45.0)$, and 43.7 (41.4, 46.0) $\mathrm{kg}$ for control, BCAA, and BCAAPG, respectively. Energy-corrected milk LSM were 50.3 $(46.8,53.7), 52.4(48.9,55.8)$, and $52.9(49.5,56.4) \mathrm{kg}$ for control, BCAA, and BCAAPG, respectively. Milk
\end{abstract}

Received August 7, 2018.

Accepted February 9, 2019.

*Corresponding author: jw37@cornell.edu urea nitrogen LSM in milk for control, BCAA, and BCAAPG were $8.60(8.02,9.22), 9.70$ (9.01, 10.45), and $9.75(9.08,10.47) \mathrm{mg} / \mathrm{dL}$. Plasma urea nitrogen concentrations LSM for control, BCAA, and BCAAPG were $8.3(7.7,8.9), 10.1(9.4,10.9)$, and $9.6(9.4,10.3)$ $\mathrm{mg} / \mathrm{dL}$, respectively. The numbers of plasma samples classified as hyperketonemia were 77, 44, and 57 in control, BCAA, and BCAAPG, respectively. The BCAA supplementation increased plasma urea nitrogen and milk urea nitrogen, free valine concentration in plasma, and decreased hyperketonemia events during the postpartum period.

Key words: mammary, branched-chain amino acids, milk synthesis, $\beta$-hydroxybutyrate

\section{INTRODUCTION}

Hundreds of AA exist in nature, but only the few known as EAA cannot be synthesized by the mammalian tissues and serve as building blocks for the synthesis of proteins. For this reason, these EAA must be absorbed from the intestine to meet AA daily requirements. Deficiencies in EAA metabolism may disrupt homeostasis in the dairy cow and affect many physiological functions such as maintenance, growth, reproduction, and lactation (Bauman and Currie, 1980; Orlando et al., 2008). During late gestation and early lactation, the dairy cow experiences an increased demand for protein to support fetal development and protein synthesis in the mammary gland and in other body tissues (Drackley, 1999; Ji and Dann, 2013; Van Saun and Sniffen, 2014). The deficit in protein intake is counterbalanced by increasing protein mobilization from body reserves such as skeletal muscle (Bell et al., 2000; Kuhla et al., 2011; Mann et al., 2016). The EAA mobilized from peripheral tissues after conversion to pyruvate, acetyl-CoA, and tricarboxylic acid cycle intermediates can be oxidized to produce ATP (Wu, 2009). The NRC (2001) reported that Lys and Met 
are the most limiting EAA for production of milk and milk protein in cows in established lactation. A recent study by Larsen et al. (2014) proposed that Leu and Lys would be the 2 most limiting EAA during early lactation based on the concentration differences of AA between mammary arterial and venous blood. Leucine, isoleucine, and valine, also known as branched-chain AA (BCAA), are 3 of the 10 known EAA. The BCAA are used for cellular and milk protein synthesis and represent up to $50 \%$ of all EAA in milk (Harper et al., 1984; Mackle et al., 1999a; Appuhamy et al., 2011). The effects of BCAA supplementation on glucose homeostasis and synthesis of other AA have been reported in several species (Shimomura et al., 2006; Torres-Leal et al., 2011; Lynch and Adams, 2014). Moreover, increased levels of circulating BCAA (particularly Leu) are potent nutrient signals that stimulate the mammalian target of rapamycin pathway, inducing increased protein synthesis, and influence the hormonal status during catabolic stages such as in early lactation dairy cows (Lynch and Adams, 2014; Yoon, 2016).

The use of propylene glycol (PG) as a treatment for hyperketonemia (HYK) has been described previously (Hoedemaker et al., 2004; McArt et al., 2011; Mann et al., 2017). Hyperketonemia is one of the most common metabolic disorders during early lactation in dairy cows due to the reduced DMI and increased demand of energy (Duffield et al., 2009; Ospina et al., 2010). Propylene glycol is fermented to propionate or lactic acid, essential substrates for gluconeogenesis, and then used for synthesis of glucose by the liver. The use of PG might help to overcome the negative energy balance (EB) and reduce the use of body reserves for gluconeogenesis during early lactation (Studer et al., 1993; Drackley et al., 2001; Nielsen and Ingvartsen, 2004). Propylene glycol as an oral drench has been shown to increase insulin and glucose concentrations in plasma (Studer et al., 1993; Miyoshi et al., 2001; Piantoni and Allen, 2015), as well as increase milk production, and decrease severity of metabolic diseases, and culling in HYK cows (McArt et al., 2012). Increased concentration of insulin stimulates synthesis of body proteins (Davis et al., 2002) and drastically reduces the concentration of free BCAA in blood (Mackle et al., 1999b), suggesting an increased use and uptake by peripheral tissues. Thus, synthesis and degradation of AA could be altered after a bolus of PG and its subsequent effects on insulin and glucose metabolism during catabolic stages (Eriksson and Björkman, 1993).

The positive effects of BCAA supplementation on milk protein yield in dairy cows have been reported before with most models using intravenous or postruminal infusion in mid lactation cows (Mackle et al., 1999a; Korhonen et al., 2002; Appuhamy et al., 2011;
Doelman et al., 2015; Nichols et al., 2016). Other studies in early to mid lactation tested the effects of BCAA on milk component yield, but the results were inconclusive (Hopkins et al., 1994; Arriola Apelo et al., 2014; Curtis et al., 2018). Nonetheless, there is significant variability in the route of $\mathrm{BCAA}$ administration and the stage of lactation across these studies with none assessing rumen-protected sources.

The PG during early lactation in dairy cows not only acts as glucose precursor but also increases insulin concentration. Insulin stimulates protein synthesis and reduce proteolysis in peripheral tissues. Moreover, Raggio et al. (2006) showed that propionate in combination with casein increased protein concentration and protein yield in dairy cows. Considering that both PG and BCAA promote protein synthesis, there may be synergy of these 2 supplements.

We hypothesized that rumen-protected BCAA (RPBCAA) supplementation alone or in combination with PG orally during early lactation in dairy cows has a beneficial role in milk yield and protein synthesis in the mammary gland, as well as altered energy and protein metabolism reflected in changes of some blood metabolites. To the best of our knowledge, this is the first study using RP-BCAA as a practical strategy to test the potential benefits of BCAA supplementation during early lactation in Holstein dairy cows. The objective of our study was to examine the effect of dietary supplementation of BCAA with or without oral PG administration on milk yield, ECM, milk composition, $\mathrm{EB}$, protein balance $(\mathbf{P B})$, and energy-related plasma metabolites during early lactation in dairy cows.

\section{MATERIALS AND METHODS}

\section{Study Population, Diets, and Treatments}

All procedures were approved by the Cornell University Institutional Animal Care and Use Committee (protocol \# 2011-0016). Holstein dairy cows $(\mathrm{n}=81$ ) from the Cornell University Ruminant Center (Harford, NY) were enrolled between January and July 2016. Inclusion criteria for enrollment were cows entering second or greater lactation and having no history of chronic lameness or mastitis during the previous lactation. Cows were enrolled $28 \mathrm{~d}$ before expected calving date, allowing them 1 wk of adaptation before the sampling period started. All cows were blocked based on their expected calving date. The randomization was carried out using the PROC PLAN (SAS 9.4, SAS Institute Inc., Cary, NC) into 1 of the 3 treatments: control ( $\mathrm{n}=$ 27) received $200 \mathrm{~g} / \mathrm{d}$ of dry molasses only from calving to 35 DIM, BCAA $(\mathrm{n}=27)$ received $550 \mathrm{~g} / \mathrm{d}$ of BCAA with $200 \mathrm{~g}$ of dry molasses from calving to 35 DIM, and 
branched-chain AA plus propylene glycol (BCAAPG; $\mathrm{n}=27$ ) received $550 \mathrm{~g} / \mathrm{d}$ of BCAA with $200 \mathrm{~g}$ of dry molasses from calving to 35 DIM plus $300 \mathrm{~mL}$ of PG as oral drench from calving until 7 DIM.

The respective BCAA-molasses mix or molasses only was offered daily as a top-dress supplement immediately after the TMR was placed in the individual bins. Consumption of the top-dress supplement was visually assessed and recorded. The BCAA was composed of $375 \mathrm{~g}$ (27\% wt/wt) of rumen-protected L-Leu, $85 \mathrm{~g}$ $(48 \% \mathrm{wt} / \mathrm{wt})$ of rumen-protected L-Ile, and $91 \mathrm{~g}(67 \%$ wt/wt) of rumen-protected L-Val. The chemical composition, in vitro rumen, and intestinal digestibility of the BCAA are presented in Table 1. Briefly, for in vitro fermentation $0.5 \mathrm{~g}$ of each RP-BCAA was incubated anaerobically under $\mathrm{CO}_{2}$ in 125 -mL Erlenmeyer flasks with Van Soest buffer $(40 \mathrm{~mL})$ and rumen fluid $(10 \mathrm{~mL})$ from 2 cows for up to $30 \mathrm{~h}$. Multiple flasks were used and samples were taken at $0,4,8,12,16,24$, and $30 \mathrm{~h}$ for determination of AA protection and release rates. After incubation, samples were filtered over Whatman 934AH filter paper (Thomas Scientific, Swedesboro, $\mathrm{NJ}$ ), rinsed with $40^{\circ} \mathrm{C}$ distilled water, and then either analyzed for nitrogen content or extracted with chloroform for further analysis via HPLC (Ross, 2013; Ross et al., 2013). Using intestinal chemical analyses, residual nitrogen was measured by block digestion and steam distillation with automatic titration [Application Note, AN300; AOAC International (2000) official method 2001.11; Foss, 2003; Tecator Digestor 20 and Kjeltec 2300 Analyzer, Foss Analytical AB, Höganäs, Sweden; Ross (2013); Ross et al. (2013)]. The BCAA were protected to prevent ruminal degradation using a lipidcoating layer with hydrogenated vegetable oil (Balchem Corporation, New Hampton, NY). The intended dose of BCAA in this study was calculated based on previous studies that effectively increased free BCAA in blood using postruminal infusion of BCAA or casein (Mackle et al., 1999a; Larsen et al., 2014). Due to discrepancies in the rumen-protected L-Leu concentration, cows in the first 10 enrollment blocks of the study received 187 $\mathrm{g}$ of L-Leu, whereas cows in blocks 11 to 27 received 375 $\mathrm{g}$ of this AA. To account for this difference and other changes that could concurrently have been associated with these 2 distinct time periods of the study (i.e., diet composition and ambient temperature), a fixed effect of period was included in all models prepartum and postpartum, and interactions with all other fixed effects were evaluated.

Cows were fed for ad libitum intake to achieve a minimum of $5 \%$ refusals. All cows were kept in sawdust bedded tiestalls and fed the same close-up dry period and fresh period TMR. Prepartum and postpartum diets were formulated with the Cornell Net Carbohydrate and
Protein System software (CNCPS; Cornell University, version 6.55, Table 2). Throughout the study, samples of prepartum and postpartum TMR were collected weekly and submitted for analysis by near-infrared reflectance spectroscopy (Cumberland Valley Analytical Services, Waynesboro, PA). Weekly samples from all forages and concentrate grains were dried, ground, and a single composite of each ingredient was analyzed for DM (method 930.15; AOAC International, 2000), CP (method 990.03; AOAC International, 2000), soluble protein (Krishnamoorthy et al., 1983), ADF (method 973.18; AOAC International, 2000), NDF (Van Soest et al., 1991), starch (Hall, 2009), sugar (DuBois et al., 1956), ash (method 942.05; AOAC International, 2000), and minerals (method 985.01; AOAC International, 2000). The chemical composition of the forages is presented in Supplemental Table S1 (https://doi.org/10 $.3168 /$ jds.2018-15508). The grain composition as formulated and an average of the weekly forage analysis was entered into the CNCPS v. 6.55 feed library to obtain predicted energy and protein content of all rations in the course of the study. Protein and energy balance as percentage of predicted requirements were calculated with CNCPS v. 6.55 for each cow during the prepartum and postpartum periods using a weekly average of BW, DMI, and either days carried calf or milk yield and milk components. Final CP across all treatment diets was calculated with CNCPS v. 6.55 as percentage of the DM using an average of the weekly feed samples. Results were similar across treatments: 15.6, 16.0, and $15.8 \%$ for control, BCAA, and BCAAPG, respectively. The duodenal flow of EAA was calculated using the mean of the DMI for each treatment on CNCPS v. 6.55.

\section{Sample Collection}

Weekly, BW was measured after morning milking and BCS was assessed using a 1 to 5 scale (Edmonson et al., 1989). Changes in BW were calculated as the BW 1 wk postpartum minus the BW at 6 wk postpartum. Calving ease on a scale of 1 to $5(1=$ normal or no assistance; 2 moderate assistance, provided by farm staff; 3 = moderate assistance, but veterinarian called as a precaution; $4=$ difficult calving, with extraction done by skilled farm staff; $5=$ very difficult calving, with maximum veterinary assistance) was recorded by farm personnel.

Postpartum, cows were milked 3 times per day and milk weights were recorded at each milking. Milk samples were collected from 3 consecutive milkings once per week, stored with bronopol at $4^{\circ} \mathrm{C}$, then analyzed within $24 \mathrm{~h}$ for fat, true protein, lactose, TS, and MUN using infrared analysis on an automated Fossomatic FT+ (Foss, Eden Prairie, MN; method 972.160; AOAC 
Table 1. Chemical composition of the rumen-protected branched-chain AA (\% of DM unless noted otherwise)

\begin{tabular}{|c|c|c|c|c|}
\hline \multirow[b]{2}{*}{ Item } & & \multicolumn{3}{|c|}{ Rumen-protected branched-chain $\mathrm{AA}^{1}$} \\
\hline & & $\mathrm{L}-\mathrm{Leu}^{2}$ & $\mathrm{~L}-\mathrm{Val}^{3}$ & $\mathrm{~L}-\mathrm{Ile}^{4}$ \\
\hline \multicolumn{5}{|l|}{ Chemical composition } \\
\hline $\mathrm{DM}, \%$ & & 99 & 99 & 100 \\
\hline $\mathrm{CP}$ & & 27 & 67 & 48 \\
\hline Soluble protein & & 9.1 & 31.9 & 36.4 \\
\hline $\mathrm{ADF}$ & & 12.3 & 1.9 & 6.7 \\
\hline aNDF & & 15.3 & 3 & 14.6 \\
\hline Starch & & 0.1 & 0.1 & 0.1 \\
\hline Ether extract & & 58.1 & 23.9 & 37.6 \\
\hline Ash & & 0.46 & 0.37 & 0.71 \\
\hline $\mathrm{Ca}$ & & 0.01 & 0 & 0 \\
\hline $\mathrm{P}$ & & 0 & 0 & 0 \\
\hline $\mathrm{Mg}$ & & 0 & 0 & 0 \\
\hline $\mathrm{K}$ & & 0.01 & 0.1 & 0.01 \\
\hline $\mathrm{S}$ & & 0.020 & 0.1 & 0.01 \\
\hline $\mathrm{Na}$ & & 0 & 0 & 0 \\
\hline $\mathrm{Cl}$ & & 0 & 0 & 0 \\
\hline \multirow[t]{6}{*}{ Rumen undigested $\mathrm{N},{ }^{5} \%$ total $\mathrm{N}$} & $4 \mathrm{~h}$ & $69.2 \pm 0.1$ & $92.9 \pm 0.9$ & $73.9 \pm 1.4$ \\
\hline & $8 \mathrm{~h}$ & $59.9 \pm 4.9$ & $89.9 \pm 0.5$ & $58.1 \pm 0.1$ \\
\hline & $12 \mathrm{~h}$ & $44.1 \pm 3.0$ & $85.8 \pm 2.6$ & $50.9 \pm 3.5$ \\
\hline & $16 \mathrm{~h}$ & $24.8 \pm 4.0$ & $74.6 \pm 0.9$ & $31.2 \pm 0.9$ \\
\hline & $24 \mathrm{~h}$ & $12.8 \pm 0.6$ & $62.2 \pm 3.5$ & $19.5 \pm 0.2$ \\
\hline & $30 \mathrm{~h}$ & $8.2 \pm 1.56$ & $52.4 \pm 0.2$ & $12.8 \pm 0.3$ \\
\hline \multirow{4}{*}{ Intestinal $\mathrm{N}$ available, ${ }^{6} \%$ total $\mathrm{N}$} & $4 \mathrm{~h}$ & 65.4 & 87.5 & 70.7 \\
\hline & $8 \mathrm{~h}$ & 57.5 & 85.0 & 55.9 \\
\hline & $12 \mathrm{~h}$ & 43.5 & 81.5 & 49.6 \\
\hline & $16 \mathrm{~h}$ & 24.0 & 71.2 & 30.4 \\
\hline
\end{tabular}

${ }^{1}$ Chemical composition was obtained with Wet Chemistry (Cumberland Valley Analytical Services, Waynesboro, PA).

${ }^{2}$ L-Leu, 27\% rumen protected (Balchem Corporation, New Hampton, NY).

${ }^{3} \mathrm{~L}-\mathrm{Val}, 67 \%$ rumen protected (Balchem Corporation).

${ }^{4} \mathrm{~L}-\mathrm{Il}$, $48 \%$ rumen protected (Balchem Corporation).

${ }^{5}$ Rumen undigested $\mathrm{N} \pm \mathrm{SD}$.

${ }^{6}$ Intestinal N available using an in vitro assay for isolating the RUP fraction of rumen-protected feedstuff and measuring its intestinal digestibility (Ross, 2013; Ross et al., 2013).

International, 2012) and SCC using optical fluorescence on a Fossomatic FC (method 972.160; AOAC International, 2012; Dairy One Cooperative Inc., Ithaca, NY). Linear scores $(\mathbf{L S})$ were calculated as LS $=[\mathrm{ln}$ $(\mathrm{SCC} / 100) / \ln (2)]+3$ (Ali and Shook, 1980). Energycorrected milk yield was calculated as follows: ECM $(\mathrm{kg})=\{[(0.0929 \times$ fat $\%)+(0.0547 \times$ true protein $\% / 0.93)+(0.0395 \times$ lactose $)] \times$ milk $(\mathrm{kg})\}(\mathrm{NRC}$, 2001).

Blood was sampled 3 times per week on Mondays, Wednesdays, and Fridays before feeding (between 0600 and $0730 \mathrm{~h}$ ) from $21 \mathrm{~d}$ before expected calving until 21 DIM from the coccygeal vessels using 20 -gauge $\times 2.54$ $\mathrm{cm}$ needles and blood collection tubes (Becton, Dickinson and Company, Franklin Lakes, NJ) containing 158 USP of sodium heparin and without anticoagulant, for plasma and serum separation, respectively. All blood samples were immediately placed on ice and plasma and serum were separated within $1 \mathrm{~h}$ at $2,800 \times g$ for 20 min at $4^{\circ} \mathrm{C}$, then stored at $-20^{\circ}$ until analysis.
Nonesterified fatty acid (NEFA) concentrations in plasma were estimated by colorimetric measurement of an enzymatic reaction [HR Series NEFA-HR (2); Wako Life Sciences, Mountain View, CA] with a microplate spectrophotometer (Epoch, Biotek, Winooski, VT) as previously described (Mann et al., 2015). Plasma urea nitrogen (PUN) concentrations were determined using a manual urease/Berhelot determination (Sigma, urea nitrogen procedure no. 640, Sigma Diagnostics, St. Louis, MO; Butler et al., 1996). Pooled plasma bovine samples were included on each NEFA and PUN plate for quality control, and the inter- and intra-plate coefficients of variation were $<5 \%$.

The plasma BHB concentration was measured using the BHB-Check ketone meter system (Pharma DOC, Lübeck, Germany) in samples thawed on ice and then warmed up briefly in a water bath to $37^{\circ} \mathrm{C}$ (Leal Yepes et al., 2018). Hyperketonemia was defined as BHB $\geq 1.2$ mmol/L (Ospina et al., 2013). Cows were not treated for HYK unless contemporaneous with anorexia, upon 
Table 2. Ingredients of dry and fresh diet formulation (\% of DM)

\begin{tabular}{|c|c|c|}
\hline Ingredient & Dry & Fresh \\
\hline Wheat straw & 21.33 & 3.38 \\
\hline Corn silage & 46.21 & 43.19 \\
\hline Haylage & - & 6.57 \\
\hline Alfalfa hay & - & 3.76 \\
\hline Amino Plus ${ }^{1}$ & 7.11 & 5.66 \\
\hline Canola meal, solvent extracted & 3.56 & 6.95 \\
\hline Corn grain, ground fine & - & 14.12 \\
\hline Citrus pulp & 4.62 & 1.87 \\
\hline Soybean hulls & 3.56 & 3.65 \\
\hline Corn gluten feed & 1.78 & - \\
\hline Megalac $\mathrm{R}^{2}$ & 0.89 & 0.43 \\
\hline Urea & & 0.21 \\
\hline Salt & - & 0.42 \\
\hline Bio-Chlor ${ }^{3}$ & 5.33 & - \\
\hline Sodium bicarbonate & - & 1.33 \\
\hline Calcium carbonate & 2.31 & 0.17 \\
\hline Calcium phosphate & - & 0.17 \\
\hline Magnesium sulfate & 0.36 & - \\
\hline Magnesium oxide & 0.44 & 0.21 \\
\hline Alimet $^{4}$ & 0.11 & 0.06 \\
\hline Megamine- $\mathrm{L}^{5}$ & - & 0.63 \\
\hline LysAAmet $^{6}$ & 1.07 & 1.60 \\
\hline Organic trace minerals ${ }^{7}$ & 0.44 & 0.21 \\
\hline Rumensin ${ }^{8}$ & 0.09 & 0.06 \\
\hline MIN-AD ${ }^{9}$ & - & 0.42 \\
\hline Dynamate $^{10}$ & - & 0.44 \\
\hline Vitamin E & 0.27 & 0.04 \\
\hline Organic selenium $0.06 \%$ & 0.52 & - \\
\hline
\end{tabular}

${ }^{1}$ Soybean product (Ag Processing Inc., Omaha, NE).

${ }^{2}$ Comercial fat (Arm \& Hammer Nutrition, Princeton, NJ).

${ }^{3}$ Anionic feed supplement (Arm \& Hammer Nutrition).

${ }^{4}$ 2-Hydroxy-4-methyl-thio-butanoic acid (Novus International, St. Charles, MO).

${ }^{5}$ Rumen bypass lysine supplement (Arm \& Hammer Nutrition).

${ }^{6}$ Rumen-protected lysine $8.3 \%$ of MP and rumen-protected methionine $5.4 \%$ of MP (Perdue AgriBusiness, Salisbury, MD).

${ }^{7}$ Composed of $25 \% \mathrm{Ca}, 6.5 \% \mathrm{Mg}, 6.3 \% \mathrm{~S}, 500 \mathrm{mg} / \mathrm{kg}$ of Fe, $13,300 \mathrm{mg} /$ $\mathrm{kg}$ of $\mathrm{Zn}, 4,000 \mathrm{mg} / \mathrm{kg}$ of $\mathrm{Cu}, 5,000 \mathrm{mg} / \mathrm{kg}$ of $\mathrm{Mn}, 125.7 \mathrm{mg} / \mathrm{kg}$ of Se, $250 \mathrm{mg} / \mathrm{kg}$ of $\mathrm{Co}$, and $300 \mathrm{mg} / \mathrm{kg}$ of I.

${ }^{8}$ Elanco Animal Health, Greenfield, IN.

${ }^{9}$ Mineral compound (MIN-AD, Amarillo, TX), contains $54 \%$ calcium carbonate, $43 \%$ magnesium carbonate.

${ }^{10}$ Feed-grade potassium and magnesium sulfate (Mosaic Global Sales, Lithia, FL), contains $18.2 \% \mathrm{~K}, 11.3 \% \mathrm{Mg}$, and $22.4 \% \mathrm{~S}$.

which they were removed from the trial and treated according to standard farm protocols. Health events were recorded on a daily basis for all cows during the study period.

A subset of samples was selected to measure the concentration of plasma AA based on critical time points during the study (e.g., enrollment, time of biopsies, and beginning, middle, and end of the treatments). Plasma free AA concentrations were determined using EZ:faast (Phenomenex, Torrance, CA) by the chromatography and diagnostic services laboratory of the Veterinary Faculty, University of Montréal, as previously described (Kassube et al., 2017). Briefly, solid-phase extraction was followed by derivatization and a liquid/liquid extraction. Derivatized samples were then analyzed by liquid chromatography-mass spectrometry using the Agilent 6100 Single Quadrupole LC/MS Systems (Agilent Inc., Santa Clara, CA) for high-throughput qualitative analyses of small molecules. For a separate objective of this study that included liver, muscle, and adipose tissue biopsies, cows received flunixin meglumine $(1.1 \mathrm{mg} / \mathrm{kg}$, IV Prevail, VetOne, Boise, ID) intravenously at d $9 \pm 4$ prepartum and $\mathrm{d} 5 \pm 1$, and $\mathrm{d} 20$ \pm 1 postpartum (data not presented).

\section{Statistical Analysis}

The sample size of 27 animals per treatment was based on identifying a biological difference between the control and the BCAA treatments in plasma concentration of free Leu of $20 \mu M$ with standard deviation of 25 $\mu M$, confidence level of $95 \%$, and power of $95 \%$. Prior to any statistical analysis, 7 cows were removed from the study for the following reasons: 1 animal in BCAA, $\mathrm{n}=1$, died as a consequence of an uterine prolapse; 1 animal in BCAA, $\mathrm{n}=1$, was removed from trial due to respiratory disease; 1 animal in control, $\mathrm{n}=1$, was unable to adapt to the tiestall; 1 animal in BCAAPG, $\mathrm{n}=$ 1 , had an incorrect breeding date; 1 animal in BCAA, $n$ $=1$, was anorexic for several days after calving; and 2 animals in BCAA, $\mathrm{n}=1$; and in BCAAPG, $\mathrm{n}=1$, were treated for suspected fatty liver following the farm's protocols, confounding the data. The numbers of cows that remained for statistical analysis were control $(\mathrm{n}=$ $26)$, BCAA $(\mathrm{n}=23)$, and BCAAPG $(\mathrm{n}=25)$.

Data from the prepartum and postpartum period were analyzed separately. Weekly averages for DMI and milk yield were calculated first and used for analysis. Chi-squared tests were performed using PROC FREQ of SAS (SAS 9.4, SAS Institute Inc.) for differences in calving scores, parity, and episodes of HYK (BHB $\geq 1.2 \mathrm{mmol} / \mathrm{L}$ ). One-way ANOVA were calculated using PROC ANOVA in SAS 9.4 for differences in days dry, BCS, and BW. Repeated-measures ANOVA was performed for the outcomes: DMI, EB, PB, milk yield, ECM yield; percentage of fat, protein, lactose, and TS; MUN, LS, free AA, BHB, NEFA, and PUN plasma concentration using PROC Mixed in SAS 9.4.

Five covariance structures were tested for each outcome (simple, compound symmetry, autoregressive order 1, Toeplitz, and unstructured). Data from free AA concentration in plasma was unequally spaced; therefore, the covariance structures analyzed for each of the models were spatial power law, Gaussian, and spherical. The covariance structure with the lowest Akaike's information criterion was selected. Fixed effects were treatment (control, BCAA, and BCAAPG) and period (period 1: $187 \mathrm{~g} / \mathrm{d}$ of L-Leu and period 2: 
Table 3. Descriptive statistics of the study population by treatment; results are presented as total counts or average $\pm \mathrm{SD}$

\begin{tabular}{|c|c|c|c|c|}
\hline \multirow[b]{2}{*}{ Measurement } & \multicolumn{3}{|c|}{ Treatment $^{1}$} & \multirow[b]{2}{*}{$P$-value } \\
\hline & Control & BCAA & BCAAPG & \\
\hline \multicolumn{5}{|l|}{ Parity } \\
\hline 2 & 15 & 13 & 16 & 0.93 \\
\hline 3 & 5 & 6 & 5 & \\
\hline$\geq 4$ & 6 & 4 & 4 & \\
\hline Days dry & $58.6 \pm 1.2$ & $56.8 \pm 1.3$ & $56.9 \pm 1.2$ & 0.49 \\
\hline BW dry, kg & $744.8 \pm 13.9$ & $717.8 \pm 14.4$ & $739.6 \pm 14.0$ & 0.27 \\
\hline BW fresh, kg & $692.7 \pm 12.2$ & $697.5 \pm 12.7$ & $711.7 \pm 12.3$ & 0.43 \\
\hline \multicolumn{5}{|l|}{ Calving score } \\
\hline 1 & 16 & 16 & 19 & 0.43 \\
\hline 2 & 8 & 6 & 3 & \\
\hline 3 & 1 & 1 & 3 & \\
\hline 4 & 1 & 0 & 0 & \\
\hline Calf weight, $\mathrm{kg}$ & $43.2 \pm 1.2$ & $41.2 \pm 1.3$ & $40.7 \pm 1.2$ & 0.31 \\
\hline
\end{tabular}

${ }^{1}$ The control received $200 \mathrm{~g}$ of dry molasses from calving to $35 \mathrm{DIM}$, branched-chain amino acids (BCAA) received $550 \mathrm{~g}$ per day of rumen-protected BCAA mixed with $200 \mathrm{~g}$ of dry molasses from calving to 35 DIM, and BCAA plus propylene glycol (BCAAPG) received $550 \mathrm{~g} / \mathrm{d}$ of BCAA mixed with $200 \mathrm{~g}$ of dry molasses from calving to 35 DIM plus $300 \mathrm{~mL}$ of propylene glycol as oral drench from calving until 7 DIM.

$375 \mathrm{~g} / \mathrm{d}$ of L-Leu) using the REPEATED statement for the time variable. Block was included in every model as a random effect. The treatment $\times$ time interaction was included into all models; other plausible interaction terms were tested and were not included in the final model if the $P$-value was $\geq 0.05$. Tukey's post hoc test was used for multiple comparison correction of $P$-values for all pairwise comparisons of least squares means. Normality and homoscedasticity of residuals were tested for each model fit. To meet the assumptions, the outcome variables BHB, NEFA, free AA, and PUN concentrations were log-transformed.

\section{RESULTS}

Descriptive statistics of the study population by treatment are presented in Table 3. The BCS is presented as median with range. At enrollment, BCS was 3.0 (3.0, 3.5 ) for the 3 treatments. In the first week postpartum, BCS for control, BCAA, and BCAAPG were 3.0 (2.75, $3.25), 3.0(2.75,3.5)$, and $3.0(2.75,3.25)$, respectively.

\section{Diet Analysis}

The diet composition analysis prepartum and postpartum is presented in Table 4 . The estimated grams per day of metabolizable BCAA were $45.8,33.2$, and $31.8 \mathrm{~g} / \mathrm{d}$ for Leu, Ile, and Val, respectively. The estimated duodenal flows of digestible EAA (CNCPS v. 6.55) are in Table 5. Postpartum, the formulated concentration of Lys and Met as \% of MP in the base diet was 7.41 and $2.75 \%$, respectively, and their ratio was 2.7:1.0. The DMI throughout prepartum period for control, BCAA, and BCAAPG is in Figure 1. Post- partum, the DMI was not different among the control, BCAA, and BCAAPG $(P=0.13)$. The BW change in kilograms $(95 \%$ CI) from 1 wk until 6 wk postpartum was $11.0 \mathrm{~kg}(-7.0,29.0), 23.6 \mathrm{~kg}(4.8,42.3)$, and 17.8 $\mathrm{kg}(-0.4,35.9)$ for control, BCAA, and BCAAPG, respectively $(P=0.54)$.

Model-predicted EB and PB pre- and postpartum are presented in Table 6 and Figure 1. The predicted energy and protein densities for the dry period diet were $2.11 \mathrm{Mcal}$ of $\mathrm{ME} / \mathrm{kg}$ of $\mathrm{DM}$ and $99.1 \mathrm{~g}$ of $\mathrm{MP} / \mathrm{kg}$ of DM.

Table 4. Average ( \pm SD) chemical composition of the diets

\begin{tabular}{lcc}
\hline Component $^{1}$ & Dry & Fresh \\
\hline DM, \% & $46.7 \pm 4.6$ & $48.5 \pm 3.18$ \\
NE $E_{\mathrm{L}}$ Mcal/kg of DM & $1.48 \pm 0.02$ & $1.63 \pm 0.01$ \\
CP, \% of DM & $13.6 \pm 0.9$ & $15.5 \pm 0.8$ \\
Soluble protein, \% of DM & $5.4 \pm 0.5$ & $6.65 \pm 0.4$ \\
ADF, \% of DM & $28.2 \pm 2.3$ & $21.6 \pm 1.6$ \\
aNDF, \% of DM & $42.2 \pm 3.3$ & $31.7 \pm 2.1$ \\
Starch, \% of DM & $19.5 \pm 3.1$ & $25.7 \pm 2.7$ \\
Ether extract, \% of DM & $3.1 \pm 0.3$ & $3.4 \pm 0.2$ \\
Ash, \% of DM & $8.2 \pm 0.7$ & $7.9 \pm 0.5$ \\
Ca, \% of DM & $1.54 \pm 0.35$ & $0.89 \pm 0.09$ \\
P, \% of DM & $0.31 \pm 0.04$ & $0.36 \pm 0.03$ \\
Mg, \% of DM & $0.52 \pm 0.07$ & $0.46 \pm 0.05$ \\
K, \% of DM & $1.20 \pm 0.16$ & $1.28 \pm 0.41$ \\
S, \% of DM & $0.42 \pm 0.05$ & $0.37 \pm 0.03$ \\
Na, \% of DM & $0.13 \pm 0.02$ & $0.77 \pm 0.11$ \\
Cl, \% of DM & $0.64 \pm 0.07$ & $0.51 \pm 0.05$ \\
DCAD, mEq/100 & $-8.05 \pm 5.5$ & $31.0 .2 \pm 5.25$ \\
g of DM & &
\end{tabular}

${ }^{1}$ Values represent averages of weekly samples composited and do not include top-dress supplement or the oral drench. Chemical composition is the average \pm SD of a weekly sampling analyzed by near-infrared reflectance spectroscopy (Cumberland Valley Analytical Services, Waynesboro, PA).

${ }^{2}$ Amylase-treated NDF. 
Table 5. Predicted postpartum diet composition

\begin{tabular}{|c|c|c|c|c|}
\hline \multirow[b]{2}{*}{ Predicted composition $^{1}$} & \multicolumn{4}{|c|}{ Treatment $^{2}$} \\
\hline & Control & BCAA & $\begin{array}{c}\text { BCAAPG } \\
\leq 7 \mathrm{DIM}\end{array}$ & $\begin{array}{c}\text { BCAAPG } \\
>7 \text { DIM }\end{array}$ \\
\hline $\mathrm{ME}, \mathrm{Mcal} / \mathrm{kg}$ of $\mathrm{DM}$ & 2.54 & 2.52 & 2.54 & 2.52 \\
\hline $\mathrm{MP}, \mathrm{g} / \mathrm{kg}$ of $\mathrm{DM}$ & 120.1 & 120.8 & 120.5 & 121.4 \\
\hline $\mathrm{MP}, \mathrm{g} / \mathrm{d}$ & 2,486 & 2,574 & 2,638 & 2,653 \\
\hline Ether extract, $\%$ of DM & 3.7 & 4.7 & 4.6 & 4.7 \\
\hline Met, $\mathrm{g} / \mathrm{d}$ & 90.8 & 91.7 & 94.5 & 95.6 \\
\hline Lys, g/d & 235.8 & 252.0 & 260.1 & 256.5 \\
\hline Arg, g/d & 181.6 & 194.3 & 200.7 & 197.8 \\
\hline Thr, g/d & 145.9 & 155.8 & 160.9 & 158.0 \\
\hline Leu, g/d & 257.3 & 284.9 & 293.7 & 290.0 \\
\hline Ile, $\mathrm{g} / \mathrm{d}$ & 143.5 & 158.6 & 164.0 & 161.4 \\
\hline Val, g/d & 183.0 & 206.7 & 213.2 & 210.4 \\
\hline His, g/d & 90.3 & 96.5 & 99.4 & 98.2 \\
\hline Phe, g/d & 161.0 & 171.9 & 177.3 & 175.0 \\
\hline $\operatorname{Trp}, \mathrm{g} / \mathrm{d}$ & 46.0 & 49.0 & 50.7 & 49.9 \\
\hline
\end{tabular}

${ }^{1}$ Predicted by Cornell Net Carbohydrate and Protein System (v 6.55, Cornell University, Ithaca, NY) based on composite forage analysis; average ingredient composition; and with observed mean DMI, BW, milk yield, and components for each treatment.

${ }^{2}$ The control received $200 \mathrm{~g}$ of dry molasses from calving to 35 DIM, branched-chain amino acids (BCAA) received $550 \mathrm{~g}$ per day of rumen-protected BCAA mixed with $200 \mathrm{~g}$ of dry molasses from calving to 35 DIM, and BCAA plus propylene glycol (BCAAPG) received $550 \mathrm{~g} / \mathrm{d}$ of BCAA mixed with $200 \mathrm{~g}$ of dry molasses from calving to 35 DIM plus $300 \mathrm{~mL}$ of propylene glycol as oral drench from calving until 7 DIM.

\section{Milk Yield and Components}

Milk yield, milk components, and ECM are summarized in Table 7 and Figure 2. The MUN was higher for treatments BCAA and BCAAPG than control $(P$ $=0.01$ ) across the whole treatment period. The BCAA and BCAAPG supplementation had no effect on ECM $(P=0.11)$. The BCAA supplementation had no effect on any other milk components analyzed. Throughout the experiment, neither milk fat yield $(P=0.14)$ nor milk protein concentration $(P=0.11)$ were affected by the treatment. An interaction between treatment and period was detected for milk protein yield $(P=0.01)$. During period 1 and 2, milk protein concentrations for control, BCAA, and BCAAPG were $3.30 \%(3.2,3.4)$ and $3.71 \%(3.5,3.93), 3.53 \%(3.4,3.7)$ and $3.69 \%(3.5$, $3.9)$, and $3.32 \%(3.2,3.5)$ and $3.76(3.6,4.0)$, respectively.

\section{Blood Metabolites}

Free BCAA concentrations in plasma during the preand postpartum periods are shown in Figure 3. Prepartum, the concentration in plasma of the $3 \mathrm{BCAA}$ did not differ among the treatments. Postpartum, average concentration of L-Leu in plasma was 80.05, 88.34, and $85.81 \mu M$ for control, BCAA, and BCAAPG, respectively $(P=0.07)$. The L-Ile concentration in plasma postpartum was $61.24,66.72$, and $62.41 \mu M$ for control, BCAA, and BCAAPG, respectively $(P=0.36)$.
The L-Val concentration in plasma postpartum was 136.81, 152.91, and 147.28 $\mu \mathrm{M}$ for control, BCAA, and BCAAPG, respectively $(P=0.04)$.

The BHB, NEFA, and PUN concentration in plasma are in Table 8. Plasma urea nitrogen was different among the control, BCAA, and BCAAPG treatments during both the dry $(P=0.02)$ and postpartum ( $P$ $=0.001)$ periods. Postpartum NEFA concentration in plasma was not affected by the supplementation with BCAA or BCAAPG $(P=0.60)$. Plasma BHB during prepartum was similar among all treatments $(P=$ 0.29 ). The concentration of plasma BHB from calving until 21 DIM was not altered by supplementation with BCAA or PG administration $(P=0.35)$. The number of plasma samples classified as HYK from calving until 21 DIM was $77 / 241$ (11.3\%), 44/213 (6.5\%), and 57/228 $(8.4 \%)$ in control, BCAA, and BCAAPG treatments, respectively $(P=0.02)$. The number of cows with at least one plasma sample classified as HYK from calving until 21 DIM was 22/26 (84.6\%), 14/23 (60.8\%), and $17 / 25(68.0 \%)$ in control, BCAA, and BCAAPG treatments, respectively $(P=0.59)$.

\section{DISCUSSION}

The overall goal of our study was to test the effect of supplementation with BCAA on milk yield, milk components, and blood metabolites during early lactation in dairy cows. Additionally, we wanted to test the effect of $\mathrm{PG}$ as a glucose precursor enhancing the response 
of BCAA due to its known effects of increasing energy status and circulating insulin, thereby sparing AA for physiological functions other than citric acid cycle intermediate, glucose, pyruvate, or acetyl-CoA production.

The BCAA supplementation with or without oral PG did not affect DMI. The lack of treatment effect on
DMI is in agreement with previous studies using BCAA or casein infusion during early lactation (Larsen et al., 2014) or mid to late lactation (Mackle et al., 1999a; Nichols et al., 2016; Curtis et al., 2018).

The EB postpartum was not affected by BCAA or BCAAPG supplementation. The CP across the 2 treatments and the control were essentially identical dur-

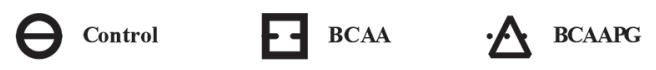

a)

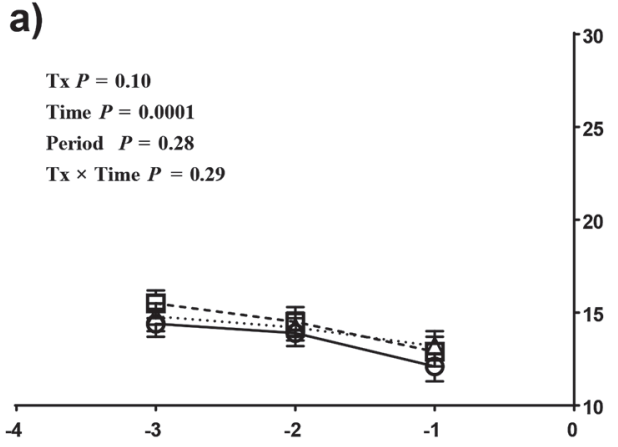

c)

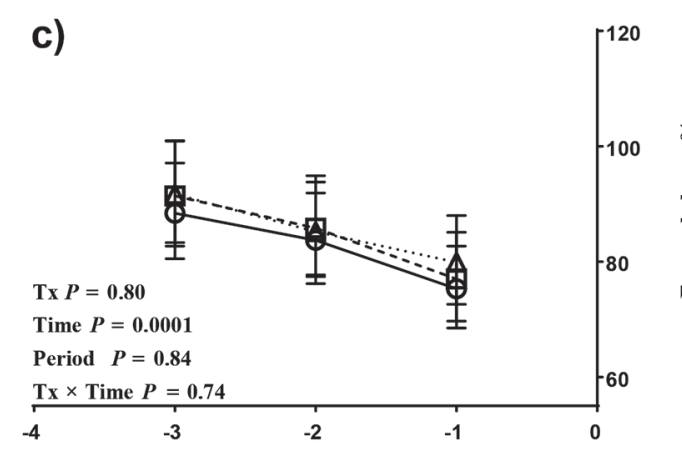

e)

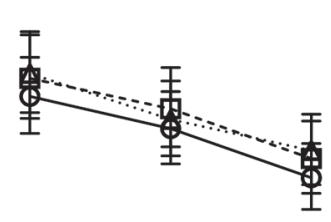

Tx $P=0.62$

Time $P=0.0001$

Period $P=0.83$

Tx $\times$ Time $P=0.66$

$-4-3$
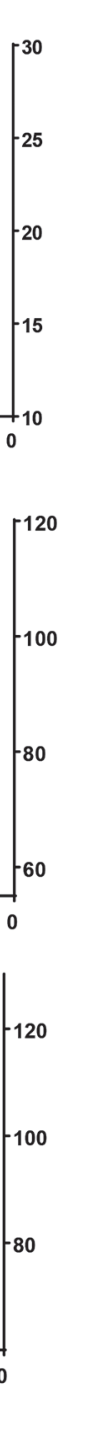
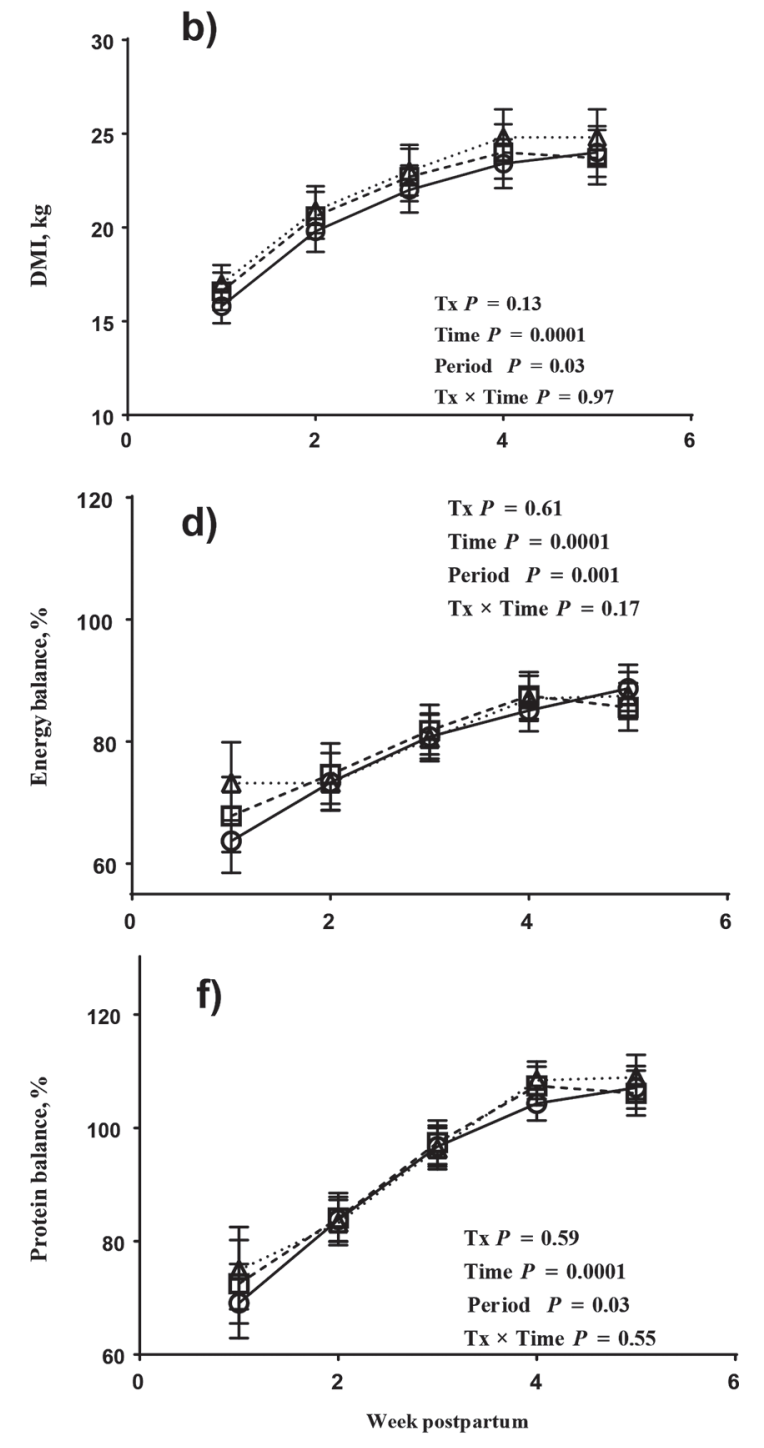

Figure 1. Data are presented as LSM and 95\% CI. Dry matter intake (kg) wk 3 to 1 prepartum (a) and wk 1 to 5 postpartum (b) for the 3 treatments. Energy balance during the prepartum period (c) and postpartum period (d) as percentage of the requirements. Protein balance during the prepartum period (e) and postpartum period (f) as percentage of the requirements. Energy and protein balance was calculated with Cornell Net Carbohydrate and Protein System (CNCPS v. 6.55, Cornell University, Ithaca, NY) for each cow during dry and fresh periods using a weekly average of BW, DMI, and either days carried calf or milk yield and milk components. The control treatment received 200 g of dry molasses from calving to 35 DIM, branched-chain amino acids (BCAA) received 550 g per day of rumen-protected BCAA mixed with 200 g of dry molasses from calving to 35 DIM, and BCAA plus propylene glycol (BCAAPG) received 550 g/d of BCAA mixed with 200 g of dry molasses from calving to 35 DIM plus $300 \mathrm{~mL}$ of propylene glycol as oral drench from calving until 7 DIM. Fixed effect of period accounts for difference and other changes associated with the 2 distinct time periods of the study (i.e., L-Leu dose, diet composition, and ambient temperature). Tx $=$ treatment. 
BRANCHED-CHAIN AMINO ACID SUPPLEMENTATION DURING 35 DIM
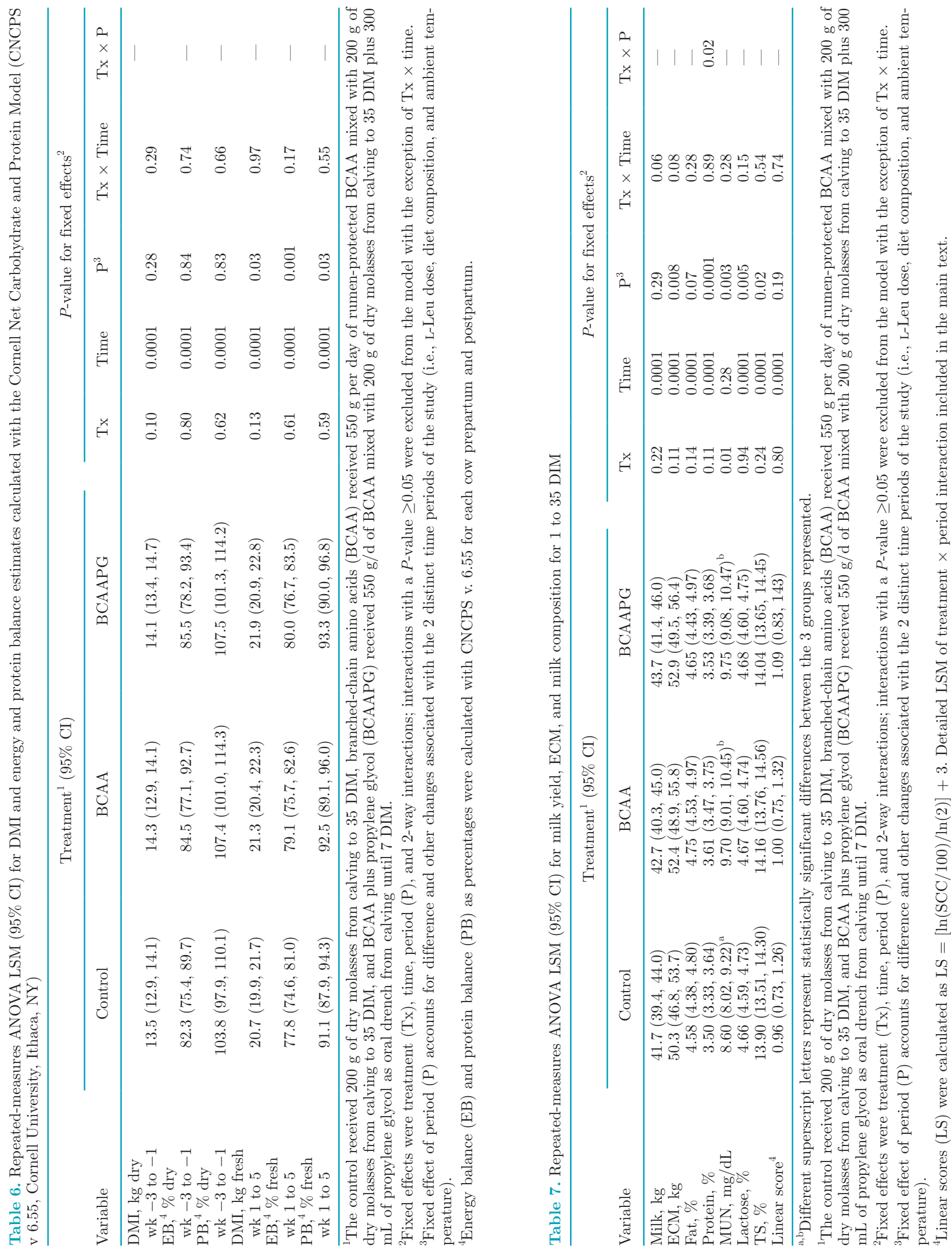


\section{$\Theta$ control $\boxminus$ BCAA $\triangle$ BCAAPG}
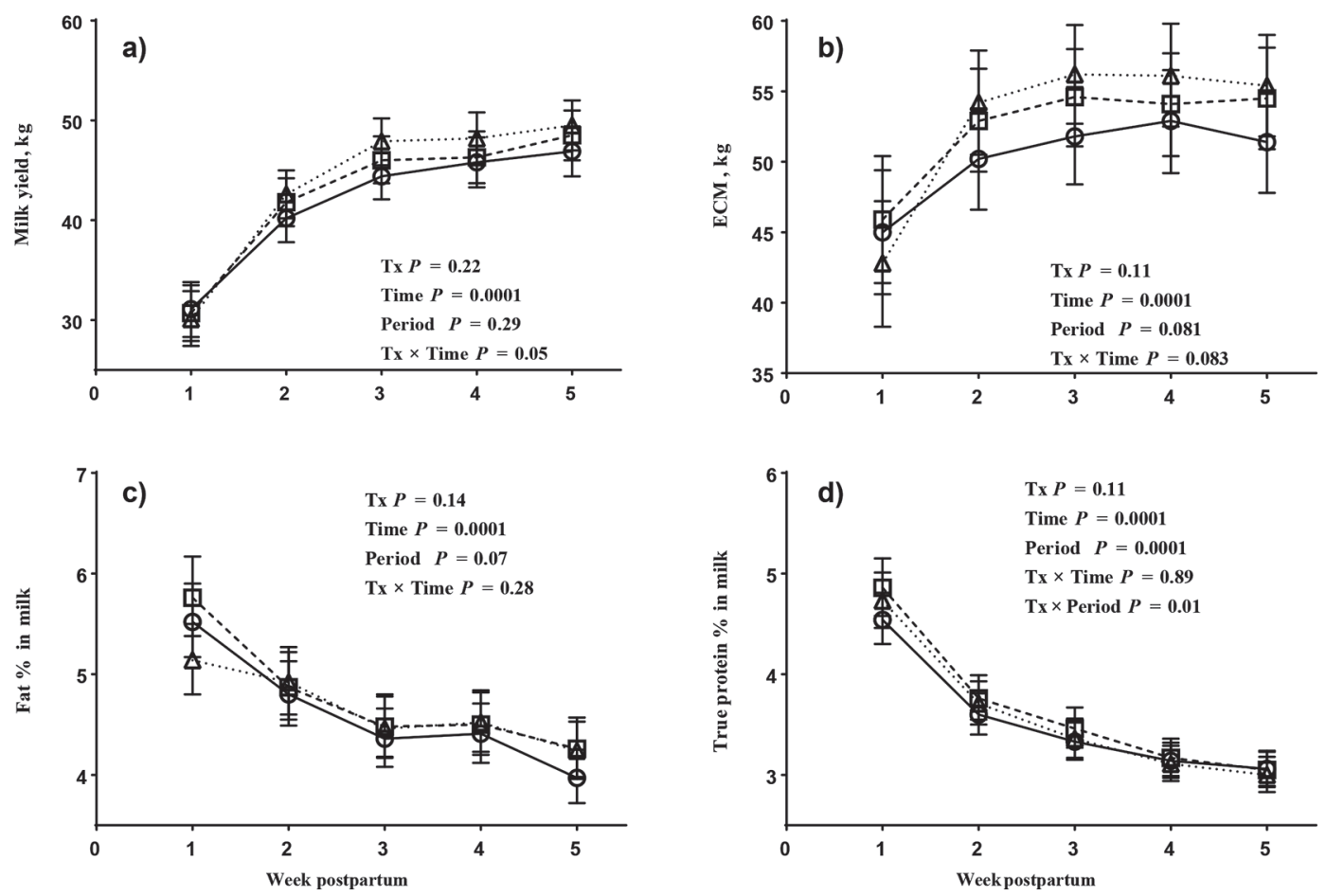

Figure 2. Least squares means and 95\% CI for ANOVA of milk yield (a), ECM (b), fat \% in milk (c), and true protein \% (d). The control treatment received $200 \mathrm{~g}$ of dry molasses from calving to 35 DIM, branched-chain amino acids (BCAA) received $550 \mathrm{~g}$ per day of rumen-protected BCAA mixed with $200 \mathrm{~g}$ of dry molasses from calving to 35 DIM, and BCAA plus propylene glycol (BCAAPG) received 550 g/d of BCAA mixed with $200 \mathrm{~g}$ of dry molasses from calving to 35 DIM plus $300 \mathrm{~mL}$ of propylene glycol as oral drench from calving until 7 DIM. Fixed effects were treatment $(\mathrm{Tx})$, time, period, and 2-way interactions; interactions with a $P$-value $\geq 0.05$ were excluded from the model with the exception of Tx $\times$ time. Fixed effect of period accounts for difference and other changes associated with the 2 distinct time periods of the study (i.e., L-Leu dose, diet composition, and ambient temperature).

ing the postpartum period. The PB postpartum was not different between control, BCAA, and BCAAPG treatments. Protein supplementation had a significant effect on DMI and milk protein yield when the diets are deficient in MP (Allen, 2000), but the response is reduced if the diets are meeting or exceeding the protein requirements (Martineau et al., 2016). The fresh cow diet in our study was formulated to exceed the MP requirements during early postpartum in dairy cows, but the average DMI in both treatments and control was lower than anticipated. Therefore, the estimated MP supply was lower than expected under the current experimental conditions. An MP deficit in early lactation is a characteristic concern in high-producing dairy cows postpartum (Bell et al., 2000; Larsen et al., 2014; Mann et al., 2015), and in combination with negative EB, suggests that even more AA may be metabolized for energy rather than for anabolic actions.

In our study, the CNCPS 6.55 model predicted an increase of BCAA duodenal flow in the treatments compared with the control, irrespective of the rumen protection which cannot be accounted for in the model. The prediction of EAA duodenal flow is a good indicator of free plasma EAA in dairy cows (Pacheco et al., 2012; Patton et al., 2015). In our study, supplementation with BCAA as a top dress from calving until 35 DIM produced an increase in free Val and Leu plasma concentrations. Sadri et al. (2017) reported an increase in plasma concentration of Leu after a single duodenal bolus infusion of Leu at a dose of $0.15 \mathrm{~g} / \mathrm{kg}$ of BW. On the other hand, Kassube et al. (2017) did not find an increase in concentrations of free plasma BCAA after intravenous infusion of Met $(12 \mathrm{~g} / \mathrm{d})$, Lys $(21 \mathrm{~g} / \mathrm{d})$, and BCAA (35 g/d of Leu, $15 \mathrm{~g} / \mathrm{d}$ of Ile, and $15 \mathrm{~g} / \mathrm{d}$ of Val). Changes in the concentration of plasma free BCAA could be due to reduced DMI, BCAA absorption in the intestine or enhanced tissue uptake for catabolism or protein synthesis. In our study, the L-Leu dose differences in the first 10 enrollment blocks might have affected the free BCAA concentration in plasma, specifically free Leu. Moreover, Sadri et al. (2017) showed an increase in plasma Leu, but did use a higher dose of 
L-Leu and a different method of intestinal delivery than in the present study. Dose and time of sampling might play a role in detecting any significant increases in free
Leu concentration in plasma. The peak of AA concentration in plasma following AA oral administration is affected by passage and degradation in the rumen, ab-

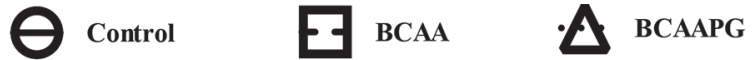
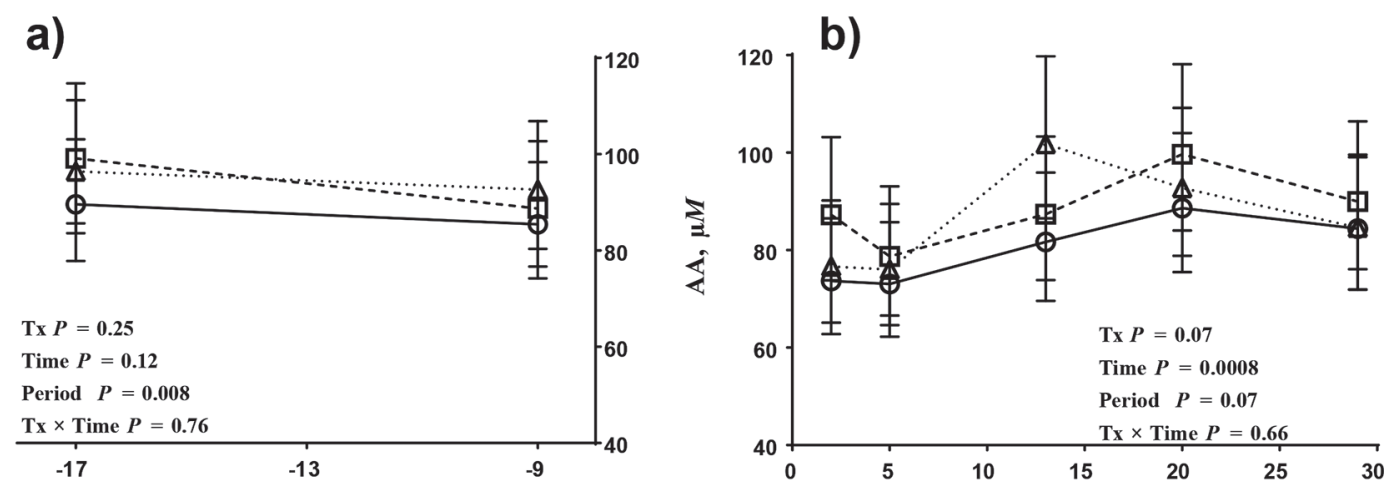

c)

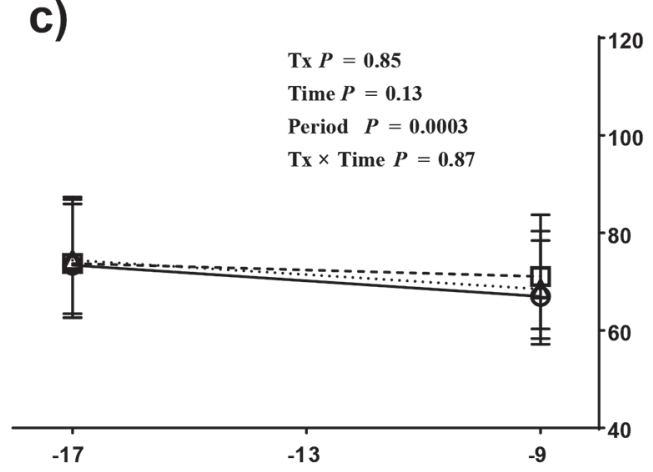

e)

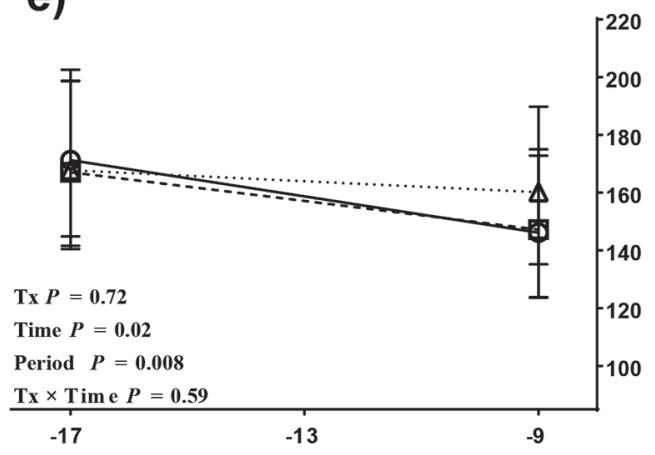

Day before calving
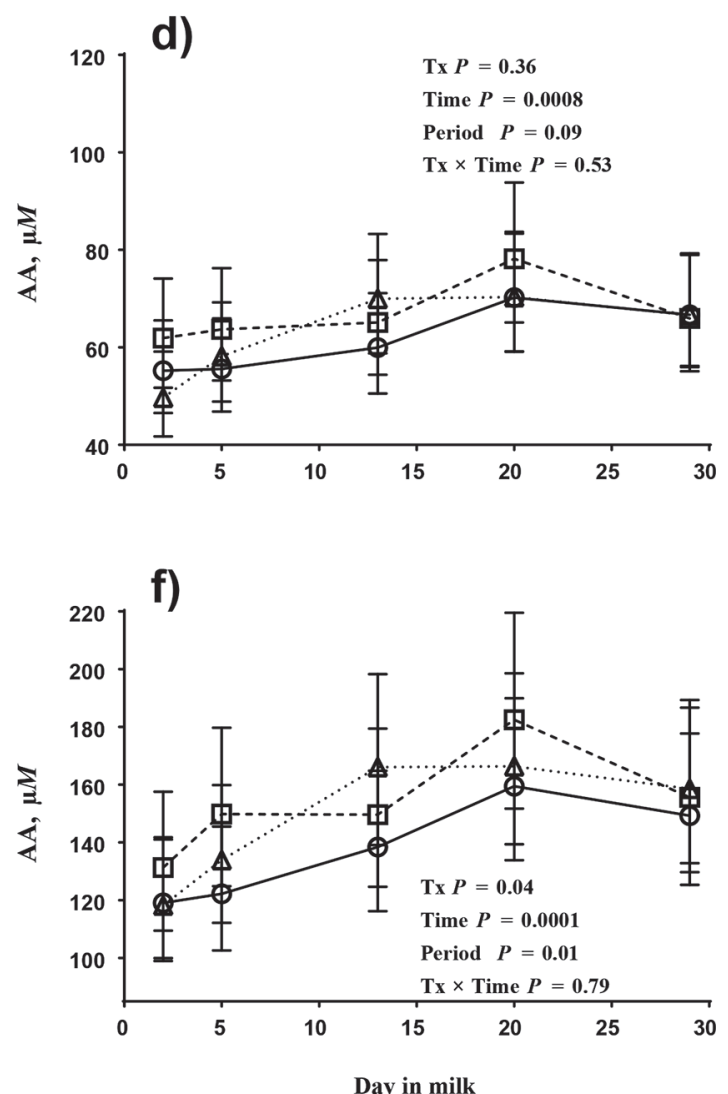

Figure 3. (a) Least squares means and 95\% CI for ANOVA of free L-Leu concentration in plasma prepartum, (b) free L-Leu concentration in plasma postpartum, (c) free L-Ile concentration in plasma prepartum, (d) free L-Ile concentration in plasma postpartum, (e) free L-Val concentration in plasma prepartum, and (f) free L-Val concentration in plasma postpartum. The control treatment received $200 \mathrm{~g}$ of dry molasses from calving to 35 DIM, branched-chain amino acids (BCAA) received $550 \mathrm{~g}$ per day of rumen-protected BCAA mixed with $200 \mathrm{~g}$ of dry molasses from calving to 35 DIM, and BCAA plus propylene glycol (BCAAPG) received $550 \mathrm{~g} / \mathrm{d}$ of BCAA mixed with $200 \mathrm{~g}$ of dry molasses from calving to 35 DIM plus $300 \mathrm{~mL}$ of propylene glycol as oral drench from calving until 7 DIM. Fixed effect of period accounts for difference and other changes associated with the 2 distinct time periods of the study (i.e., L-Leu dose, diet composition, and ambient temperature). Tx $=$ treatment. 


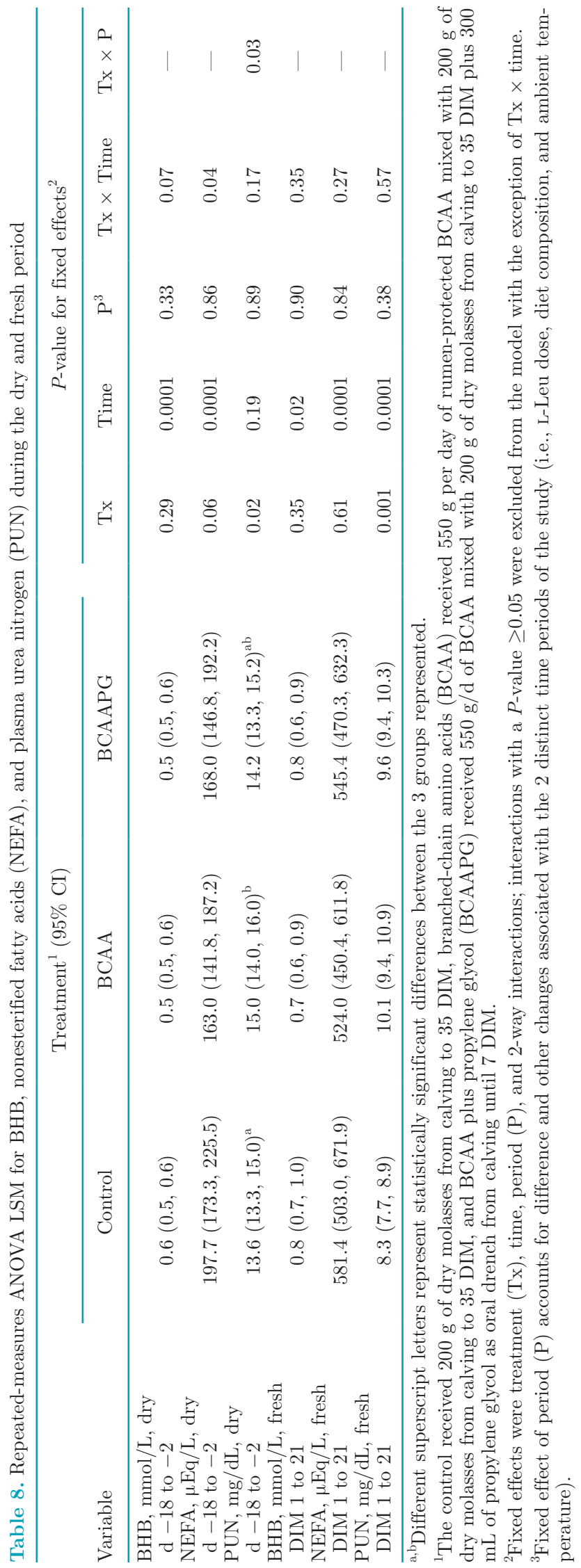

sorption time, and first bypass hepatic metabolism, all affecting accumulation of the AA in the blood stream (Koenig and Rode, 2001).

Even though milk yield and ECM were not statistically altered by BCAA or BCAAPG supplementation during early lactation, mean milk yield, and mean ECM were numerically lower in the control than BCAA or BCAAPG. Milk yield response to BCAA or casein infusion has been reported before, ranging from no to small response (Broderick et al., 1970; Appuhamy et al., 2011; Doelman et al., 2015) to a substantial increase (McCormick et al., 1999; Larsen et al., 2014). Milk production differences among the studies could be caused by different factors including the dose of BCAA or other EAA infused, stage of lactation at time of treatment, and other limiting nutrients in the diets (Larsen et al., 2014).

In our study, all cows received $430 \mathrm{~g}$ of rumen-protected fat in the form of calcium salt (Megalac) postpartum. In addition, the both BCAA and BCAAPG treatments received approximately and extra $364 \mathrm{~g}$ consisting of a lipid-coating layer with soy-based hydrogenated vegetable oil. A meta-analysis on the effects of fat addition in diets in dairy cows on milk production and components reported that the expected milk production response to fat supplementation would be around $1.05 \mathrm{~kg} /$ cow increase per d (Rabiee et al., 2012). In this meta-analysis, the average increase in dietary ether extract to produce this milk yield increase was $2.59 \%$ of DM (Rabiee et al., 2012). The ether extract concentrations in treatments and control diets were approximately 4.7 and $3.7 \%$, suggesting a $1 \%$ difference. Therefore, we believe that the small differences in our observed outcomes of interest could be due to this small increase in fat consumption.

More importantly, we were most interested in the potential increase in percentage of milk protein that has been observed after AA supplementation in dairy cows (Rulquin et al., 2006; Appuhamy et al., 2011), but BCAA supplementation did not alter milk composition in our study. Mammary gland uptake of BCAA is in excess of what is necessary for protein synthesis (Bequette et al., 1998). The partitioning of EAA in the body changes during anabolic and catabolic stages (Bequette et al., 1997), and oxidation of AA in splanchnic, muscle, and other tissues may be a limiting factor for protein synthesis in the mammary gland (Reynolds et al., 1994). Differences in milk protein yield were similar among all control and treatments and may be due to seasonal variation due to weather (deep cold or excessive heat) or feedstuff variability (or both), and thus, are unlikely to be due to the differences in L-Leu as both control and treatments groups were affected equally. 
In the present study, MUN and PUN concentrations were increased with BCAA supplementation similar to previous studies infusing BCAA (Nichols et al., 2016) and casein (Martineau et al., 2017). High concentrations of MUN and PUN point out an overall surplus of nitrogen in the cow and might be caused by several factors including energy-protein imbalance in the diet (Kohn, 2007), increased flow of ammonia across the rumen wall, and absorption of AA from the small intestine (Roseler et al., 1993; Broderick and Clayton, 1997; Huhtanen et al., 2015). The MUN and PUN did not differ between BCAA and BCAAPG, suggesting that added gluconeogenic precursors in the form of PG did not improve any energy-protein imbalances postpartum. Before calving, the control had the lowest DMI among all treatments, this might negatively affect the PUN concentration during the dry period. Postpartum, the DMI and CP among control, BCAA, and BCAAPG were similar; therefore, the differences in PUN and MUN concentration among the treatments are likely due to the deamination or transamination (or both) of supplemental BCAA for energy or other metabolic processes.

Mammary gland uptake of BCAA from blood is often in excess of what is required for typical milk protein yield (Wohlt et al., 1977; Lei et al., 2012). In mammary cells, free BCAA may be used for synthesis of milk proteins, preserved within the cell for structural proteins synthesis, used as precursor for different metabolic and catabolic processes, or passed unaltered into milk, blood, or lymph (Mepham, 1982; Meijer et al., 1995; Larsen et al., 2015). The mammary cells from different species can oxidize BCAA and show an increase in expression of the 2 major catabolic enzymes of BCAA during lactation (Wohlt et al., 1977; DeSantiago et al., 1998). This increase in catabolism of BCAA might be a source of nitrogen and carbon skeletons for synthesis of non-EAA within the mammary cells. The variety of metabolic pathways for free BCAA might explain the lack of response in milk components in our study, or our dose was not appropriate to alter these parameters.

The prophylactic administration of $\mathrm{PG}$ was not associated with any improvements in productive or reproductive performance in dairy cows (Hoedemaker et al., 2004; Chung et al., 2009a), but PG was effective for reducing blood metabolites associated with lipolysis such as NEFA and BHB (Pickett et al., 2003; McArt et al., 2012). Despite the positive effects of $P G$ as oral drench in hyperketonemic cows (McArt et al., 2011; Gordon et al., 2017), the use of PG as a blanket therapy has shown discrepant results. Some studies have shown positive effects such as reducing NEFA and BHB concentrations, while increasing insulin concentrations in blood when different doses of PG were administered as oral drench as a blanket therapy (Chung et al., 2009b; Maurer et al., 2017). Other studies have shown no effect on milk yield, milk components, EB, BHB, or NEFA concentrations in blood when liquid or dry PG was offered as a top dress or mixed into the TMR (Chibisa et al., 2008; Chung et al., 2009a; Lomander et al., 2012). However, there is evidence of unaffected BHB concentrations after oral drench $300 \mathrm{~mL}$ of $\mathrm{PG}$ as a blanket therapy in dairy cows (Formigoni et al., 1996). In our study, the BCAA treatment had significantly fewer plasma samples classified as HYK compared with the control and BCAAPG treatment. Supplementation with BCAA in other species improves glucose metabolism in skeletal muscle, adipose tissue, and liver (Kawaguchi et al., 2011). Isoleucine, in particular, has been shown to increase NEFA oxidation in skeletal muscle and liver in mice (Nishimura et al., 2010), and Leu is likely a nutrient signal that can affect DMI as well as EB (Lynch and Adams, 2014; Yoon, 2016), suggesting further examination of hepatic metabolism is warranted, in light of fewer hyperketonemic events.

When interpreting the results of our study, a significant limitation is the absence of a treatment group with PG supplementation alone, and therefore we are unable to isolate the effect caused by PG. Despite this, few differences between the BCAA and BCAAPG treatments were noted, making it unlikely that $\mathrm{PG}$ alone was responsible for observed differences in comparison with the control. The dose of BCAA used during the present study was formulated based on previous studies using postruminal infusion of BCAA and casein in mid and early lactation in dairy cows. The quantities needed to produce a measurable effect on production using BCAA supplementation during early lactation require more evaluation.

\section{CONCLUSIONS}

We presented the effects of BCAA with or without PG supplementation during early lactation in dairy cows on different productive parameters and concentration of energy metabolites. We conclude that BCAA supplementation in this study did not have an effect on DMI, milk yield, and milk protein. However, BCAA increased PUN and MUN as well as free Val concentration in plasma. The BCAA alone reduced the number of plasma samples classified as HYK during the first 21 DIM. For this reason, the use of BCAA as a supplement for dairy cattle deserves further investigation to fully understand the effects of BCAA in NEFA and BHB metabolism. 


\section{ACKNOWLEDGMENTS}

This study was supported by the Agriculture and Food Research Initiative competitive Grant No. 201267015-30230 from the USDA National Institute of Food and Agriculture (Washington, DC). The authors thank Balchem Corporation (New Hampton, NY) for donating the rumen-protected BCAA. The authors thank John Leahy, Conor McCabe, Sarah Elizabeth LaCount, Allison Lawton Kerwin, Ben Kasl, Amy Vasquez, and Rodrigo Molano Torres (Cornell University, Ithaca, NY) for their invaluable help during this project. We also want to thank the staff at the Cornell research dairy farm for taking care of the animals enrolled in our study.

\section{REFERENCES}

Ali, A. K. A., and G. E. Shook. 1980. An optimum transformation for somatic cell concentration in milk. J. Dairy Sci. 63:487-490. https: //doi.org/10.3168/jds.S0022-0302(80)82959-6.

Allen, M. S. 2000. Effects of diet on short-term regulation of feed intake by lactating dairy cattle. J. Dairy Sci. 83:1598-1624. https:// doi.org/10.3168/jds.S0022-0302(00)75030-2.

AOAC International. 2000. Official Methods of Analysis. 17th ed. AOAC International, Gaithersburg, MD.

AOAC International. 2012. Official Methods of Analysis. 19th ed. AOAC International, Gaithersburg, MD.

Appuhamy, J. A. D. R. N., J. R. Knapp, O. Becvar, J. Escobar, and M. D. Hanigan. 2011. Effects of jugular-infused lysine, methionine, and branched-chain amino acids on milk protein synthesis in highproducing dairy cows. J. Dairy Sci. 94:1952-1960. https://doi.org/ $10.3168 /$ jds.2010-3442.

Arriola Apelo, S. I., L. M. Singer, X. Y. Lin, M. L. McGilliard, N. R. St-Pierre, and M. D. Hanigan. 2014. Isoleucine, leucine, methionine, and threonine effects on mammalian target of rapamycin signaling in mammary tissue. J. Dairy Sci. 97:1047-1056. https:// doi.org/10.3168/jds.2013-7348.

Bauman, D. E., and W. B. Currie. 1980. Partitioning of nutrients during pregnancy and lactation: a review of mechanisms involving homeostasis and homeorhesis. J. Dairy Sci. 63:1514-1529.

Bell, A. W., W. S. Burhans, and T. R. Overton. 2000. Protein nutrition in late pregnancy, maternal protein reserves and lactation performance in dairy cows. Proc. Nutr. Soc. 59:119-126.

Bequette, B. J., F. R. Backwell, A. G. Calder, J. A. Metcalf, D. E. Beever, J. C. MacRae, and G. E. Lobley. 1997. Application of a U-13C-labeled amino acid tracer in lactating dairy goats for simultaneous measurements of the flux of amino acids in plasma and the partition of amino acids to the mammary gland. J. Dairy Sci. 80:2842-2853. https://doi.org/10.3168/jds.S0022-0302(97)76249 -0 .

Bequette, B. J., F. R. Backwell, and L. A. Crompton. 1998. Current concepts of amino acid and protein metabolism in the mammary gland of the lactating ruminant. J. Dairy Sci. 81:2540-2559. https: //doi.org/10.3168/jds.S0022-0302(98)70147-X.

Broderick, G. A., and M. K. Clayton. 1997. A statistical evaluation of animal and nutritional factors influencing concentrations of milk urea nitrogen. J. Dairy Sci. 80:2964-2971. https://doi.org/10 .3168/jds.S0022-0302(97)76262-3.

Broderick, G. A., T. Kowalczyk, and L. D. Satter. 1970. Milk production response to supplementation with encapsulated methionine per Os or casein per abomasum. J. Dairy Sci. 53:1714-1721. https: //doi.org/10.3168/jds.S0022-0302(70)86468-2.

Butler, W. R., J. J. Calaman, and S. W. Beam. 1996. Plasma and milk urea nitrogen in relation to pregnancy rate in lactating dairy cattle. J. Anim. Sci. 74:858-865. https://doi.org/10.2527/1996 $.744858 x$.

Chibisa, G. E., G. N. Gozho, A. G. Van Kessel, A. A. Olkowski, and T. Mutsvangwa. 2008. Effects of peripartum propylene glycol supplementation on nitrogen metabolism, body composition, and gene expression for the major protein degradation pathways in skeletal muscle in dairy cows. J. Dairy Sci. 91:3512-3527. https://doi.org/ 10.3168/jds.2007-0920.

Chung, Y. H., I. D. Girard, and G. A. Varga. 2009a. Effects of feeding dry propylene glycol to early postpartum Holstein dairy cows on production and blood parameters. Animal 3:1368-1377. https:// doi.org/10.1017/S1751731109990292.

Chung, Y. H., C. M. Martinez, N. E. Brown, T. W. Cassidy, and G. A. Varga. 2009b. Ruminal and blood responses to propylene glycol during frequent feeding. J. Dairy Sci. 92:4555-4564. https://doi .org/10.3168/jds.2009-2131.

Curtis, R. V., J. J. M. Kim, J. Doelman, and J. P. Cant. 2018. Maintenance of plasma branched-chain amino acid concentrations during glucose infusion directs essential amino acids to extra-mammary tissues in lactating dairy cows. J. Dairy Sci. 101:4542-4553. https: //doi.org/10.3168/jds.2017-13236.

Davis, T. A., M. L. Fiorotto, D. G. Burrin, P. J. Reeds, H. V. Nguyen, P. R. Beckett, R. C. Vann, and P. M. J. O'Connor. 2002. Stimulation of protein synthesis by both insulin and amino acids is unique to skeletal muscle in neonatal pigs. Am. J. Physiol. Endocrinol. Metab. 282:E880-E890. https://doi.org/10.1152/ajpendo.00517 2001 .

DeSantiago, S., N. Torres, A. Suryawan, A. R. Tovar, and S. M. Hutson. 1998. Regulation of branched-chain amino acid metabolism in the lactating rat. J. Nutr. 128:1165-1171.

Doelman, J., J. J. M. Kim, M. Carson, J. A. Metcalf, and J. P. Cant. 2015. Branched-chain amino acid and lysine deficiencies exert different effects on mammary translational regulation. J. Dairy Sci. 98:7846-7855. https://doi.org/10.3168/jds.2015-9819.

Drackley, J. K. 1999. Biology of dairy cows during the transition period: The final frontier? J. Dairy Sci. 82:2259-2273. https://doi .org/10.3168/jds.S0022-0302(99)75474-3.

Drackley, J. K., T. R. Overton, and G. N. Douglas. 2001. Adaptations of glucose and long-chain fatty acid metabolism in liver of dairy cows during the periparturient period. J. Dairy Sci. 84:E100-E112. https://doi.org/10.3168/jds.S0022-0302(01)70204-4.

Dubois, M., K. A. Gilles, J. K. Hamilton, P. A. Rebers, and F. Smith. 1956. Colorimetric method for determination of sugars and related substances. Anal. Chem. 28:350-356.

Duffield, T. F., K. D. Lissemore, B. W. McBride, and K. E. Leslie. 2009. Impact of hyperketonemia in early lactation dairy cows on health and production. J. Dairy Sci. 92:571-580. https://doi.org/ $10.3168 /$ jds.2008-1507.

Edmonson, A. J., I. J. Lean, L. D. Weaver, T. Farver, and G. Webster. 1989. A body condition scoring chart for Holstein dairy cows. J. Dairy Sci. 72:68-78. https://doi.org/10.3168/jds.S0022 -0302(89)79081-0.

Eriksson, L. S., and O. Björkman. 1993. Influence of insulin on peripheral uptake of branched chain amino acids in the 60-hour fasted state. Clin. Nutr. 12:217-222. https://doi.org/10.1016/0261 -5614(93)90018-Y.

Formigoni, A., M.-C. Cornil, A. Prandi, A. Mordenti, A. Rossi, D. Portetelle, and R. Renaville. 1996. Effect of propylene glycol supplementation around parturition on milk yield, reproduction performance and some hormonal and metabolic characteristics in dairy cows. J. Dairy Res. 63:11-24. https://doi.org/10.1017/ S0022029900031502.

Gordon, J. L., S. J. LeBlanc, D. F. Kelton, T. H. Herdt, L. Neuder, and T. F. Duffield. 2017. Randomized clinical field trial on the effects of butaphosphan-cyanocobalamin and propylene glycol on ketosis resolution and milk production. J. Dairy Sci. 100:3912-3921. https://doi.org/10.3168/jds.2016-11926.

Hall, M. B. 2009. Analysis of starch, including maltooligosaccharides, in animal feeds: A comparison of methods and a recommended method for AOAC collaborative study. J. AOAC Int. 92:42-49. 
Harper, A. E., R. H. Miller, and K. P. Block. 1984. Branched-chain amino acid metabolism. Annu. Rev. Nutr. 4:409-454. https://doi .org/10.1146/annurev.nu.04.070184.002205.

Hoedemaker, M., D. Prange, H. Zerbe, J. Frank, A. Daxenberger, and H. H. D. Meyer. 2004. Peripartal propylene glycol supplementation and metabolism, animal health, fertility, and production in dairy cows. J. Dairy Sci. 87:2136-2145. https://doi.org/10.3168/ jds.S0022-0302(04)70033-8.

Hopkins, B. A., A. H. Rakes, T. E. Daniel, C. A. Zimmerman, and W. J. Croom. 1994. Effects of intraperitoneal L-leucine, L-isoleucine, L-valine, and L-Arginine on milk fat depression in early lactation cows. J. Dairy Sci. 77:1084-1092. https://doi.org/10.3168/jds .S0022-0302(94)77043-0.

Huhtanen, P., E. H. Cabezas-Garcia, S. J. Krizsan, and K. J. Shingfield. 2015. Evaluation of between-cow variation in milk urea and rumen ammonia nitrogen concentrations and the association with nitrogen utilization and diet digestibility in lactating cows. J. Dairy Sci. 98:3182-3196. https://doi.org/10.3168/jds.2014-8215.

Ji, P., and H. M. Dann. 2013. Negative protein balance: Implications for fresh and transition cows. In Cornell Nutrition Conference for Feed Manufacturers. Department of Animal Science in the College of Agriculture and Life Sciences at Cornell University, Syracuse, NY.

Kassube, K. R., J. D. Kaufman, K. G. Pohler, J. W. McFadden, and A. G. Rius. 2017. Jugular-infused methionine, lysine and branchedchain amino acids does not improve milk production in Holstein cows experiencing heat stress. Animal 11:2220-2228. https://doi .org/10.1017/S1751731117001057.

Kawaguchi, T., N. Izumi, M. R. Charlton, and M. Sata. 2011. Branched-chain amino acids as pharmacological nutrients in chronic liver disease. Hepatology 54:1063-1070. https://doi.org/ 10.1002/hep. 24412 .

Koenig, K. M., and L. M. Rode. 2001. Ruminal degradability, intestinal disappearance, and plasma methionine response of rumenprotected methionine in dairy cows. J. Dairy Sci. 84:1480-1487. https://doi.org/10.3168/jds.S0022-0302(01)70181-6.

Kohn, R. 2007. Use of milk or blood urea nitrogen to identify feed management inefficiencies and estimate nitrogen excretion by dairy cattle and other animals. Pages $1-15$ in Proc. Florida Ruminant Nutrition Symposium, Gainesville, FL. University of Florida, Gainesville.

Korhonen, M., A. Vanhatalo, and P. Huhtanen. 2002. Evaluation of isoleucine, leucine, and valine as a second-limiting amino acid for milk production in dairy cows fed grass silage diet. J. Dairy Sci. 85:1533-1545. https://doi.org/10.3168/jds.S0022-0302(02)74223 -9 .

Krishnamoorthy, U., C. J. Sniffen, M. D. Stern, and P. J. VanSoest. 1983. Evaluation of a mathematical model of rumen digestion and an in vitro simulation of rumen proteolysis to estimate rumenundegraded nitrogen content of feedstuffs. Br. J. Nutr. 50:555-568.

Kuhla, B., G. Nurnberg, D. Albrecht, S. Gors, H. M. Hammon, and C. C. Metges. 2011. Involvement of skeletal muscle protein, glycogen, and fat metabolism in the adaptation on early lactation of dairy cows. J. Proteome Res. 10:4252-4262. https://doi.org/10.1021/ pr200425h.

Larsen, M., C. Galindo, D. R. Ouellet, G. Maxin, N. B. Kristensen, and H. Lapierre. 2015. Abomasal amino acid infusion in postpartum dairy cows: Effect on whole-body, splanchnic, and mammary amino acid metabolism. J. Dairy Sci. 98:7944-7961. https://doi .org/10.3168/jds.2015-9439.

Larsen, M., H. Lapierre, and N. B. Kristensen. 2014. Abomasal protein infusion in postpartum transition dairy cows: Effect on performance and mammary metabolism. J. Dairy Sci. 97:5608-5622. https://doi.org/10.3168/jds.2013-7247.

Leal Yepes, F. A., D. V. Nydam, W. Heuwieser, and S. Mann. 2018 Technical note: Evaluation of the diagnostic accuracy of 2 pointof-care $\beta$-hydroxybutyrate devices in stored bovine plasma at room temperature and at $37^{\circ} \mathrm{C}$. J. Dairy Sci. 101:6455-6461. https://doi .org/10.3168/jds.2017-13960

Lei, J., D. Feng, Y. Zhang, S. Dahanayaka, X. Li, K. Yao, J. Wang, Z. Wu, Z. Dai, and G. Wu. 2012. Regulation of leucine catabo- lism by metabolic fuels in mammary epithelial cells. Amino Acids 43:2179-2189. https://doi.org/10.1007/s00726-012-1302-2.

Lomander, H., J. Frossling, K. L. Ingvartsen, H. Gustafsson, and C. Svensson. 2012. Supplemental feeding with glycerol or propylene glycol of dairy cows in early lactation-effects on metabolic status, body condition, and milk yield. J. Dairy Sci. 95:2397-2408. https: //doi.org/10.3168/jds.2011-4535.

Lynch, C. J., and S. H. Adams. 2014. Branched-chain amino acids in metabolic signalling and insulin resistance. Nat. Rev. Endocrinol. 10:723-736. https://doi.org/10.1038/nrendo.2014.171.

Mackle, T. R., D. A. Dwyer, and D. E. Bauman. 1999a. Effects of branched-chain amino acids and sodium caseinate on milk protein concentration and yield from dairy cows. J. Dairy Sci. 82:161-171. https://doi.org/10.3168/jds.S0022-0302(99)75220-3.

Mackle, T. R., D. A. Dwyer, K. L. Ingvartsen, P. Y. Chouinard, J. M. Lynch, D. M. Barbano, and D. E. Bauman. 1999b. Effects of insulin and amino acids on milk protein concentration and yield from dairy cows. J. Dairy Sci. 82:1512-1524. https://doi.org/10.3168/ jds.S0022-0302(99)75378-6.

Mann, S., A. Abuelo, D. V. Nydam, F. A. Leal Yepes, T. R. Overton, and J. J. Wakshlag. 2016. Insulin signaling and skeletal muscle atrophy and autophagy in transition dairy cows either overfed energy or fed a controlled energy diet prepartum. J. Comp. Physiol. B 186:513-525. https://doi.org/10.1007/s00360-016-0969-1.

Mann, S., F. A. L. Yepes, E. Behling-Kelly, and J. A. A. McArt. 2017. The effect of different treatments for early-lactation hyperketonemia on blood $\beta$-hydroxybutyrate, plasma nonesterified fatty acids, glucose, insulin, and glucagon in dairy cattle. J. Dairy Sci. 100:6470-6482. https://doi.org/10.3168/jds.2016-12532.

Mann, S., F. A. L. Yepes, T. R. Overton, J. J. Wakshlag, A. L. Lock, C. M. Ryan, and D. V. Nydam. 2015. Dry period plane of energy: Effects on feed intake, energy balance, milk production, and composition in transition dairy cows. J. Dairy Sci. 98:3366-3382. https://doi.org/10.3168/jds.2014-9024.

Martineau, R., D. R. Ouellet, E. Kebreab, and H. Lapierre. 2016. Casein infusion rate influences feed intake differently depending on metabolizable protein balance in dairy cows: A multilevel metaanalysis. J. Dairy Sci. 99:2748-2761. https://doi.org/10.3168/jds .2015-10427.

Martineau, R., D. R. Ouellet, E. Kebreab, R. R. White, and H. Lapierre. 2017. Relationships between postruminal casein infusion and milk production, and concentrations of plasma amino acids and blood urea in dairy cows: A multilevel mixed-effects meta-analysis. J. Dairy Sci. 100:8053-8071. https://doi.org/10.3168/jds.2016 $-11813$.

Maurer, M., W. Peinhopf, J. Gottschalk, A. Einspanier, G. Koeller, and T. Wittek. 2017. Effects of different dosages of propylene glycol in dry cows and cows in early lactation. J. Dairy Res. 84:375384. https://doi.org/10.1017/S0022029917000486.

McArt, J. A., D. V. Nydam, and G. R. Oetzel. 2012. A field trial on the effect of propylene glycol on displaced abomasum, removal from herd, and reproduction in fresh cows diagnosed with subclinical ketosis. J. Dairy Sci. 95:2505-2512. https://doi.org/10.3168/ jds.2011-4908.

McArt, J. A. A., D. V. Nydam, P. A. Ospina, and G. R. Oetzel. 2011. A field trial on the effect of propylene glycol on milk yield and resolution of ketosis in fresh cows diagnosed with subclinical ketosis. J. Dairy Sci. 94:6011-6020. https://doi.org/10.3168/jds.2011 $-4463$.

McCormick, M. E., D. D. French, T. F. Brown, G. J. Cuomo, A. M. Chapa, J. M. Fernandez, J. F. Beatty, and D. C. Blouin. 1999. Crude protein and rumen undegradable protein effects on reproduction and lactation performance of Holstein cows. J. Dairy Sci. 82:2697-2708. https://doi.org/10.3168/jds.S0022-0302(99)75526 -8 .

Meijer, G. A. L., J. Van Der Meulen, J. G. M. Bakker, C. J. Van Der Koelen, and A. M. Van Vuuren. 1995. Free amino acids in plasma and muscle of high yielding dairy cows in early lactation. J. Dairy Sci. 78:1131-1141. https://doi.org/10.3168/jds.S0022 -0302(95)76730-3. 
Mepham, T. B. 1982. Amino acid utilization by lactating mammary gland. J. Dairy Sci. 65:287-298. https://doi.org/10.3168/jds.S0022 $-0302(82) 82191-7$

Miyoshi, S., J. L. Pate, and D. L. Palmquist. 2001. Effects of propylene glycol drenching on energy balance, plasma glucose, plasma insulin, ovarian function and conception in dairy cows. Anim. Reprod. Sci. 68:29-43. https://doi.org/10.1016/S0378-4320(01)00137-3.

NRC. 2001. Nutrient Requirements of Dairy Cattle: Seventh Revised Edition, 2001. The National Academies Press, Washington, DC.

Nichols, K., J. J. M. Kim, M. Carson, J. A. Metcalf, J. P. Cant, and J. Doelman. 2016. Glucose supplementation stimulates peripheral branched-chain amino acid catabolism in lactating dairy cows during essential amino acid infusions. J. Dairy Sci. 99:1145-1160. https://doi.org/10.3168/jds.2015-9912.

Nielsen, N. I., and K. L. Ingvartsen. 2004. Propylene glycol for dairy cows: A review of the metabolism of propylene glycol and its effects on physiological parameters, feed intake, milk production and risk of ketosis. Anim. Feed Sci. Technol. 115:191-213. https://doi .org/10.1016/j.anifeedsci.2004.03.008.

Nishimura, J., T. Masaki, M. Arakawa, M. Seike, and H. Yoshimatsu. 2010. Isoleucine prevents the accumulation of tissue triglycerides and upregulates the expression of PPARalpha and uncoupling protein in diet-induced obese mice. J. Nutr. 140:496-500. https://doi .org/10.3945/jn.109.108977.

Orlando, G. F., G. Wolf, and M. Engelmann. 2008. Role of neuronal nitric oxide synthase in the regulation of the neuroendocrine stress response in rodents: Insights from mutant mice. Amino Acids 35:17-27. https://doi.org/10.1007/s00726-007-0630-0.

Ospina, P. A., J. A. McArt, T. R. Overton, T. Stokol, and D. V. Nydam. 2013. Using nonesterified fatty acids and $\beta$-hydroxybutyrate concentrations during the transition period for herd-level monitoring of increased risk of disease and decreased reproductive and milking performance. Vet. Clin. North Am. Food Anim. Pract. 29:387-412. https://doi.org/10.1016/j.cvfa.2013.04.003.

Ospina, P. A., D. V. Nydam, T. Stokol, and T. R. Overton. 2010. Evaluation of nonesterified fatty acids and $\beta$-hydroxybutyrate in transition dairy cattle in the northeastern United States: Critical thresholds for prediction of clinical diseases. J. Dairy Sci. 93:546554. https://doi.org/10.3168/jds.2009-2277.

Pacheco, D., R. A. Patton, C. Parys, and H. Lapierre. 2012. Ability of commercially available dairy ration programs to predict duodenal flows of protein and essential amino acids in dairy cows. J. Dairy Sci. 95:937-963. https://doi.org/10.3168/jds.2011-4171.

Patton, R. A., A. N. Hristov, C. Parys, and H. Lapierre. 2015. Relationships between circulating plasma concentrations and duodenal flows of essential amino acids in lactating dairy cows. J. Dairy Sci. 98:4707-4734. https://doi.org/10.3168/jds.2014-9000.

Piantoni, P., and M. S. Allen. 2015. Evaluation of propylene glycol and glycerol infusions as treatments for ketosis in dairy cows. J. Dairy Sci. 98:5429-5439. https://doi.org/10.3168/jds.2015-9476.

Pickett, M. M., M. S. Piepenbrink, and T. R. Overton. 2003. Effects of propylene glycol or fat drench on plasma metabolites, liver composition, and production of dairy cows during the periparturient period. J. Dairy Sci. 86:2113-2121. https://doi.org/10.3168/jds S0022-0302(03)73801-6.

Rabiee, A. R., K. Breinhild, W. Scott, H. M. Golder, E. Block, and I. J. Lean. 2012. Effect of fat additions to diets of dairy cattle on milk production and components: A meta-analysis and metaregression. J. Dairy Sci. 95:3225-3247. https://doi.org/10.3168/ jds.2011-4895.
Raggio, G., G. E. Lobley, S. Lemosquet, H. Rulquin, and H. Lapierre. 2006. Effect of casein and propionate supply on whole body protein metabolism in lactating dairy cows. Can. J. Anim. Sci. 86:81-89.

Reynolds, C. K., D. L. Harmon, and M. J. Cecava. 1994. Absorption and delivery of nutrients for milk protein synthesis by portaldrained viscera. J. Dairy Sci. 77:2787-2808. https://doi.org/10 .3168/jds.S0022-0302(94)77220-9.

Roseler, D. K., J. D. Ferguson, C. J. Sniffen, and J. Herrema. 1993 Dietary protein degradability effects on plasma and milk urea nitrogen and milk nonprotein nitrogen in Holstein cows. J. Dairy Sci 76:525-534. https://doi.org/10.3168/jds.S0022-0302(93)77372-5.

Ross, D. 2013. Methods to analyze feeds for nitrogen fractions and digestibility for ruminants with application for the CNCPS. Doctor of Philosophy. Animal Science, Cornell University, Ithaca, NY. https://hdl.handle.net/1813/33993.

Ross, D. A., M. Gutierrez-Botero, and M. E. Van Amburgh. 2013. Development of an in vitro intestinal digestibility assay for ruminant feeds. Pages 190-202 in Proc. Cornell Nutrition Conference for Feed Manufacturers, East Syracuse, NY.

Rulquin, H., B. Graulet, L. Delaby, and J. C. Robert. 2006. Effect of different forms of methionine on lactational performance of dairy cows. J. Dairy Sci. 89:4387-4394. https://doi.org/10.3168/jds .S0022-0302(06) 72485-7.

Sadri, H., D. von Soosten, U. Meyer, J. Kluess, S. Danicke, B. Saremi, and H. Sauerwein. 2017. Plasma amino acids and metabolic profiling of dairy cows in response to a bolus duodenal infusion of leucine. PLoS One 12:e0176647. https://doi.org/10.1371/journal .pone.0176647.

Shimomura, Y., Y. Yamamoto, G. Bajotto, J. Sato, T. Murakami, N. Shimomura, H. Kobayashi, and K. Mawatari. 2006. Nutraceutical effects of branched-chain amino acids on skeletal muscle. J. Nutr. 136:529S-532S. https://doi.org/10.1093/jn/136.2.529S.

Studer, V. A., R. R. Grummer, S. J. Bertics, and C. K. Reynolds. 1993. Effect of prepartum propylene glycol administration on periparturient fatty liver in dairy cows. J. Dairy Sci. 76:2931-2939. https://doi.org/10.3168/jds.S0022-0302(93)77633-X.

Torres-Leal, F. L., M. H. Fonseca-Alaniz, G. F. Teodoro, M. D. de Capitani, D. Vianna, L. C. Pantaleao, E. M. Matos-Neto, M. M. Rogero, J. Donato Jr., and J. Tirapegui. 2011. Leucine supplementation improves adiponectin and total cholesterol concentrations despite the lack of changes in adiposity or glucose homeostasis in rats previously exposed to a high-fat diet. Nutr. Metab. (Lond.) 8:62. https://doi.org/10.1186/1743-7075-8-62.

Van Saun, R. J., and C. J. Sniffen. 2014. Transition cow nutrition and feeding management for disease prevention. Vet. Clin. North Am. Food Anim. Pract. 30:689-719. https://doi.org/10.1016/j.cvfa 2014.07.009.

Van Soest, P. J., J. B. Robertson, and B. A. Lewis. 1991. Methods for dietary fiber, neutral detergent fiber, and nonstarch polysaccharides in relation to animal nutrition. J. Dairy Sci. 74:3583-3597.

Wohlt, J. E., J. H. Clark, R. G. Derrig, and C. L. Davis. 1977. Valine, leucine, and isoleucine metabolism by lactating bovine mammary tissue. J. Dairy Sci. 60:1875-1882. https://doi.org/10.3168/jds .S0022-0302(77)84118-0.

Wu, G. 2009. Amino acids: Metabolism, functions, and nutrition. Amino Acids 37:1-17. https://doi.org/10.1007/s00726-009-0269-0.

Yoon, M. S. 2016. The emerging role of branched-chain amino acids in insulin resistance and metabolism. Nutrients 8:E405. https://doi .org/10.3390/nu8070405. 